NBER WORKING PAPER SERIES

\title{
SOCIAL SECURITY AND RETIREMENT \\ IN THE U.S.
}

Peter Diamond

Jonathan Gruber

Working Paper 6097

\section{NATIONAL BUREAU OF ECONOMIC RESEARCH 1050 Massachusetts Avenue \\ Cambridge, MA 02138 \\ July 1997}

This paper is part of the NBER Project on International Social Security Comparisons. We are grateful to Alain Jousten and Karl Critz for exceptional research assistance, to David Wise and the participants in the International Social Security Comparisons project for helpful comments, to the National Science Foundation for financial support, and for a grant from the National Institute on Aging to the National Bureau of Economic Research. This paper is part of NBER's research programs in Aging, Labor Studies and Public Economics. Any opinions expressed are those of the authors and not those of the National Bureau of Economic Research.

(C) 1997 by Peter Diamond and Jonathan Gruber. All rights reserved. Short sections of text, not to exceed two paragraphs, may be quoted without explicit permission provided that full credit, including $\mathbb{C}$ notice, is given to the source. 
Social Security and Retirement in the U.S.

Peter Diamond and Jonathan Gruber

NBER Working Paper No. 6097

July 1997

JEL Nos. H55, J26

Aging, Labor Studies and Public Economics

\section{ABSTRACT}

The largest entitlement program in the United States today is the Social Security program (SS). We provide an overview of the interaction between the SS system and retirement behavior. We begin by documenting historical trends in labor force participation and program receipt, and contemporaneous patterns of work and income receipt for the current cohort of older persons. We then present an overview of the structure of the SS program in the U.S., and review existing evidence on the relationship between SS and retirement. Finally, we present results of a simulation model which measures the implicit tax/subsidy rate on work after age 55 through the SS system. We find that, for married workers, the system is roughly neutral with respect to work after age 62 , but that it heavily penalizes work after age 65 . But there are larger tax rates on single workers and on high earning workers.

Peter Diamond

Department of Economics

Massachusetts Institute of Technology

Room E52-355

50 Memorial Drive

Cambridge, MA 02139

and NBER

pdiamond@mit.edu
Jonathan Gruber

U.S. Treasury Department

Room 3454

1500 Pennsylvania Avenue

Washington, DC 20220

and NBER

jonathan.gruber@ms01.do.treas.sprint.com 
The largest entitlement program in the United States today is the Social Security program (SS). Social Security benefits payments in 1993 amounted to $\$ 267.8$ billion, which is over $18 \%$ of the federal budget and over $4 \%$ of U.S. GDP in that year; this represents a doubling as share of GDP in the past 30 years. Social Security in the U.S. is also a system in fiscal imbalance. The convergence of three trends in the early 21 st century will cause problems with the long run solvency of the program. Two of these trends are the aging of the "baby boom" cohort and the drop in the fertility rate of U.S. families. As a result, the ratio of persons over age 65 to those aged $20-64$ has risen from 0.14 in 1950 to 0.21 today, and is projected to rise to 0.36 by 2030 and to 0.41 by 2070 . The final trend is the reduction in the rate of growth in real wages in the U.S., which has lowered the base of earnings on which SS benefits commitments can be financed. As a result, current estimates imply that if the structure of the program remains unchanged, payroll taxes to finance this program, currently at $12.4 \%$ of payroll, would have to rise to over $18 \%$ (Stuerle and Bakija, 1994).

As a result of this fiscal imbalance in the SS program, a number of alternatives for reform have been considered, ranging from benefit reductions or tax increases, to increased taxation of SS benefits, raising the age of normal or early retirement, or even shifting partly or wholly into a funded (privatized) system. A critical input into understanding the efficiency implications of each of these alternatives is a model of how SS affects retirement decisions. Social Security is a dominant feature of the opportunity set facing older households in the U.S. Ranking households where the head is over age 65 by the share of their income from Social Security, Social Security represents $51 \%$ of total family income at the median; for $16 \%$ of such households, Social Security is the only source of family income. ${ }^{1}$ As a result, it seems likely that the structure of the Social Security program has important effects on the life-cycle savings and labor supply decision-making of households, and in

\footnotetext{
'Authors' tabulations of March 1994 and 1995 Current Population Survey.
} 
particular on their retirement decisions.

The purpose of our paper is to provide an overview of the interaction between SS and the labor force behavior of older persons in the U.S. We do so in four steps. First, in Part I, we document the pertinent facts about the labor market behavior of older persons in the U.S., both today and over time. Then, in Part II, we describe of the structure of the SS system in the U.S., summarizing the relevant institutional details for thinking about retirement behavior. Finally, in Part III, we present the results of a simulation model designed to document the retirement incentives inherent in SS for current cohorts of retirees. We conclude our analysis in Part IV.

\section{Part I: The Labor Market Behavior of Older Persons in the U.S.}

One of the most striking trends in the U.S. labor market over the 20th century has been the declining attachment to the labor force of older persons. In 1950, almost $60 \%$ of men age $65-69$ were participating in the labor force. By 1990 , this figure had fallen to $26 \%$. This dramatic shift in the lifestyles of older men has prompted a large literature on its proximate causes, and a leading candidate is the growth of the SS program over this same time period. But before addressing the effects of SS, it is useful to provide some more background on the labor market behavior of older men and women.

The historical and contemporaneous facts presented in this section are drawn from a number of different data sources. These are summarized in Appendix I. In that appendix, we also provide a brief overview of the databases that are used by researchers in the U.S. to study retirement behavior.

Historical Trends 
Figures 1 and 2 graph the labor force participation rates of men and women in different age groups since 1960 . We focus on four age groups: $45-54 ; 55-59 ; 60-64$; and 65 plus. For men, there is a decline in the labor force participation of all of these groups. The decline for the youngest group is slight, while the decline for $60-64$ year olds is much more precipitous. There is also a large percentage decline, albeit from a smaller base, for the oldest group.

For women, the pattern is quite different: any trend towards earlier retirement is dominated by increased labor force participation across cohorts. Even for those age 60-64, participation is rising; for the oldest group, participation declines slightly.

One first pass approach to considering whether SS is associated with these labor force trends is to examine related trends in SS generosity. We do so in three ways. First, in Figure 3, we show the share of the workforce covered by the SS system. By 1960 , a very high share of the workforce was already covered by SS, although it grew steadily over the next 30 years. An important break in the series is after 1983, when a major reform brought several new sectors into the SS system; this reform is described further below.

Second, in Figure 4, we show the share of men and women over age 55 receiving SS benefits, as well as the share receiving SS or Disability Insurance (DI) benefits. ${ }^{2}$ There was a dramatic increase in the share of the older population receiving payments from these public schemes over time. In 1960 , fewer than $40 \%$ of older men, and fewer than $20 \%$ of older women, received SS and DI benefits. By 1993, over 55\% of older men were receiving SS, and over $65 \%$ were receiving either SS or DI. For women, the percentage growth has been even more dramatic, so that by 1993 roughly $40 \%$ of women are receiving SS or DI; the net contribution of DI is much smaller

\footnotetext{
${ }^{2} \mathrm{SS}$ benefits receipt refers to receipt of retired worker benefits only, which is restricted to those age 62 and above. DI receipt refers to receipt of disabled worker benefits, which is not age restricted; but we use DI recipients of age 55 and above in the numerator of our calculation.
} 
for women than for men.

Third, we show the change in generosity of benefits payments over time in Figure 5 . We show the replacement rate from 1960 to 1991 for low earnings, medium earnings, and high earnings workers. These replacement rates are computed for a 65 year old single worker. In fact, SS replacement rates were roughly constant until 1970 for all three groups. Replacement rates then grew dramatically from 1970 to 1980 , for reasons that are described below; this growth was especially dramatic for low earners, who saw their replacement rates rise by $50 \%$, to $75 \%$ of their previous earnings level. Replacement rates then fell fairly precipitously beginning in 1981 . For high earners, their replacement rates are now actually lower than in 1970, while for average earners and low earners they remain somewhat higher.

These time series patterns yield a mixed picture of the influence of SS. Clearly, there is a strong correlation between the size of the program and the labor force participation rate of older men. But the decline in participation of older men has continued unabated in the 1980s and 1990s, even as program generosity has declined. For women, any effects of Social Security are swamped by secular trends in time series behavior.

\section{Labor Market Behavior in 1995}

For a more detailed understanding of the time pattern of labor force participation in recent times, we turn to the March 1994 and 1995 Current Population Survey (CPS). The CPS is a large nationally representative survey which asks individuals about their labor force attachment at both the point of the survey and the previous year, as well as about income in the previous year. We pool two years of the CPS for added precision in our estimates of labor force participation by age.

The age pattern of non-participation for men and women is depicted in Figure 6. At age 45, 
the participation of men is significantly higher, although almost $80 \%$ of 45 year old women are working in 1994/5. There is then a gradual parallel decline for men and women until age 55, at which the age pace steepens; this is particularly true for men, so that the participation gap closes substantially by age 62 . By age 75 , participation has dropped quite low, with fewer than $20 \%$ of men and $10 \%$ of women participating in the labor force.

Figure 7 considers in more detail the allocation of time among men as they age, by dividing activities at each age into employment, unemployment, disability, and retirement. The top line, showing the share of men employed, mirrors the age trend in Figure 6. There is very little age trend in either unemployment or disability, although both categories do shrink over time. The dominating trend here is increased retirement with age. This same exercise is repeated for women in Figure 8; the patterns are very similar to those for men, although a much larger share of women are in "other" activities that are not captured by these four metrics (as can be seen by taking one minus the sum of the four values).

\section{Income Sources of Older Persons}

Figures 9 and 10 examine the incidence of public and private retirement income for older persons. Figure 9 graphs three series for men only: the rate of Social Security recipiency; the rate of recipiency of Disability Insurance and Supplemental Security Income (SSI); and the rate of recipiency of income from other public assistance programs. ${ }^{3}$ Before age 62 , there is relatively little receipt of public assistance income among men. There is a declining pattern of other public assistance receipt, which is offset by a rising pattern of DI/SSI receipt. It is somewhat surprising

\footnotetext{
${ }^{3} \mathrm{SSI}$ is cash welfare for low income elders; the other categories represented here are Unemployment Insurance, Workers' Compensation, and cash welfare (through the AFDC program or state welfare programs).
} 
that below age 62 a large number of men actually report receiving SS benefits. Some of this may be due to miscoding of DI or SSI income; indeed, the reported number of age 60 recipients of DI in the CPS data is only about $2 / 3$ of the administrative totals. Some of this may be due to miscoding of family SS receipt as own receipt among men with older wives, but this can only explain a small share of the total. And some may be due to simple miscoding, either of age or of the type of income being received.

In any case, beginning at age 62, the rate of recipiency of SS skyrockets, until it is over $95 \%$ for those over the age of 75 . It is interesting to note that this increase in SS recipiency is associated to a small extent with a decline in DI/SSI recipiency. This suggests that the net government cost of increase SS recipiency after age 62 is somewhat smaller than the SS budget alone would suggest.

Figure 10 displays the percent of men and women at each age who are receiving private pension income on their own account (as opposed to survivor benefits from a spouse's pension). This grows fairly rapidly from age 55 on, particularly for men, so that there is a rapidly growing gender gap; by age 75 , the rate of receipt for men is twice that for women. At the same time, however, some older women will be benefitting from survivor benefits paid through their husband's pension.

Finally, Figure 11 shows the distribution of income sources for couples, arrayed by the age of the head of the family. ${ }^{4}$ We consider the distribution of income across four sources: earnings, capital income, private pensions, and public transfers (predominantly SS for older couples, as shown in Figure 11). Earnings is the dominant source of family income until age 60, although even for this younger subset of the sample over $30 \%$ of income comes from other sources. Beginning at age 60 ,

\footnotetext{
${ }^{4}$ This differs somewhat from previous figures, where the unit of observation is the older person; we do this since these income concepts are best measured at the family level.
} 
earnings and capital income decline in proportion terms, and private pensions and public income (especially the latter) grow as shares of income. The high share of income accounted for by public sector income at older ages highlights the importance of SS for workers making their retirement decisions.

\section{Part II: Key Features of the Social Security System}

History of the SS System in the U.S.

The landmark Social Security Act of 1935 created Social Security, as well as the Aid to Dependent Children program which was the start of today's cash welfare system. Originally, the Act required that all workers in commerce and industry (except railroads) under age 65 be covered by Social Security. Over the years the coverage of workers has steadily expanded; today the only significant group of workers not covered by Social Security are some of State and Local Government employees. At first, benefits for workers were only available for retired workers over age 65 . In 1956, benefits (reduced for early retirement) were made available to women between ages 62 and 65. In 1961, the same treatment was extended to men. Dependents and survivors benefits were introduced in 1939, with benefits for wives and widows over age 65 and children under age 18. In 1950 benefits were extended to dependent husbands and widowers over age 65 . In 1965 divorced wives became eligible for benefits provided the marriage had lasted at least 10 years, with similar treatment extended to divorced husbands in 1983. In 1956, benefits were extended to disabled workers over 50, with extension to disabled workers of all ages in 1960.

Until 1972, it took an Act of Congress to increase benefits. Tiring of the repeated struggle over how much to increase benefits, the 1972 Act introduced automatic increases in benefits with increases in the Consumer Price Index. This was done by continuing to base benefit on a lifetime 
average of earnings in nominal terms, but increasing the benefit formula (as a function of lifetime earnings) in step with inflation. Unfortunately, since inflation affects both lifetime nominal earnings and the relationship between benefits and earnings, this Act overindexed benefits. While this overindexing might have been roughly offset by the nonlinearities in the benefit formula had inflation remained low, with the large increase in inflation in the 1970's, this overindexing led to a large unintended increase in benefits which placed the financing of Social Security in trouble.

In 1977 , the current benefit structure was adopted. After reaching retirement age, there is continued adjustment of benefits for increases in the CPI. Determination of the level of benefits when reaching retirement age is now based on lifetime earnings using wage indexing. For each worker there is calculation of the worker's Average Indexed Monthly Earnings - an average of a worker's earnings (indexed by the average level of wages in the economy each year) over the highest 35 years of his or her career. The indexing is still not done quite right, with a gap of two years between the year used for the wage indexing of earnings (when the worker turns 60) and the year that CPI increases begin (when the worker turns 62) and no indexing of earnings after age 60 . This gap would become important if we had large and varying inflation rates. There has been controversy over the generations (referred to as the notch babies) affected by the transition to the new system.

The last major reform of Social Security came in 1983, in the face of an imminent shortage of funds. This act addressed both short-run and long-run financial problems. The most notable of the changes affecting long-run considerations is a phased increase in the Normal Retirement Age (NRA), from the current level of 65 to 67 , which is reached for workers reaching age 62 in 2022 and later. As legislated in 1983, the change in NRA does not change the age at which people can first claim retirement benefits, which remains at age 62 . But the amount of benefits received at age

\footnotetext{
${ }^{5}$ See Krueger and Pischke (1992) for a further discussion of the notch babies.
} 
62, or at any other age, is made smaller if the NRA is larger. When the NRA is 67 , a worker retiring at age 62 will receive $70 \%$ of the benefit formula amount (PIA), rather than the $80 \%$ received now. Taxation of part of Social Security benefits began with the 1983 legislation. Also the incentive to continue working past the NRA was increased. Someone first claiming benefits after the NRA has benefits increased by a Delayed Retirement Credit. The 1977 legislation raised this credit to $3 \%$ per year, while the 1983 legislation phased in increases until the credit reaches $8 \%$ per year.

The Social Security System was created in the same Act that also created a program to provide aid to poor elderly. In the early days, the elderly received more income from the welfare portion of this act than from social security. Over time, social security has outstripped aid to the aged; currently, the SS program is roughly ten times as large as the program of welfare for low income elderly and disabled (Supplemental Security Income, or SSI).

\section{Current Features of the SS System}

The Social Security system in the U.S. today is financed by a payroll tax which is levied on workers and firms equally. The total payroll tax paid by each party is 7.65 percentage points; 5.3 percentage points are devoted to the Old Age and Survivors Insurance (OASI) program, with 0.9 percentage points funding the Disability Insurance (DI) system and 1.45 percentage points funding Medicare's Hospital Insurance (HI) program. The payroll tax which funds OASI and DI is only levied up to the first $\$ 62,700$ (in 1996) of earnings (the taxable maximum); the HI tax is uncapped. ${ }^{6}$ This earnings limit, like many other earnings figures in the law, is indexed to increase with average

${ }^{6}$ This cap is 2.4 times the median earnings of a full-year (48 weeks or more), full-time (35 hours or more per week) worker; $92 \%$ of such workers earn less than this amount. 
earnings in the economy. Part of the revenue from the income taxation of Social Security benefits goes to SS. SS also receives interest (at market rates) on its holdings of Treasury debt.

Individuals qualify for an OAI pension by working for $\mathbf{4 0}$ quarters in covered employment, which encompasses most sectors of the economy in recent years. ${ }^{7}$ The process of determination of the level of benefits proceeds in several steps. The first step for qualifying workers is computation of the worker's Averaged Indexed Monthly Earnings (AIME), which is $1 / 12$ th of the average of the worker's annual earnings in covered employment, indexed by a national wage index. This real wage history is averaged over the highest 35 years of earnings. Earlier, a shorter averaging period was used to reflect the immaturity of the system. A key feature of this process is that additional higher earnings years can replace earlier lower earnings years since only 35 years are used in the calculation. ${ }^{8}$

The next step of the benefits calculation is to convert the AIME into the Primary Insurance Amount (PIA). This is done by applying a three-piece linear progressive schedule to an individual's average earnings, whereby 90 cents of the first dollar of earnings is converted to benefits, while only 15 cents of the last dollar of earnings (up to the taxable maximum) is so converted. As a result, the rate at which SS replaces past earnings (the "replacement rate") falls with the level of lifetime

\footnotetext{
${ }^{7}$ Notable exceptions are state and local employees, where some are covered and some are not covered. The current Advisory Council has recommended mandatory coverage in this sector, starting with newly hired workers. Many of these workers will receive benefits anyway because of covered work, before, after, or as a second job during their current employment.

${ }^{8}$ In particular, while earnings through age 59 are converted to real dollars for averaging, earnings after age 60 are treated nominally. There is a two-year lag in availability of the wage index, calling for a base in the year in which the worker turns 60 in order to be able to compute benefits for workers retiring at their 62 nd birthdays. While it would be possible to make adjustments as data become available, this is not done, with all later years entering the AIME calculation without any adjustment for further growth in the national average wage index. This gap would become important if we had large and varying inflation rates.
} 
earnings. For a worker with no dependents whose earnings had grown at the same rate as average earnings in the economy and who retired at age 65 in 1995 with a 1994 level of earnings of $\$ 15,000$, the replacement rate is $50 \%$. For 1994 earnings levels of $\$ 25,000, \$ 35,000$, and $\$ 45,000$, the replacement rates are $43 \%, 37 \%$, and $30 \%$. For someone who always earned the maximum amount subject to taxation, the replacement rate is $24 \%$. While $85 \%$ of SS benefits are subject to tax for retirees with sufficiently high incomes (couples with incomes above $\$ 32,000$ in 1993), all of earnings are taxed (including the employee portion of the payroll tax), raising the effective replacement rate of the program. Also, many SS recipients are in a lower tax bracket than before retirement.

Adjustments to the level of the PIA are made based on the age at which benefits are first claimed. For workers claiming before the Normal Retirement Age (currently 65, but legislated to slowly increase to 67), benefits are decreased by $5 / 9$ of one percent per month, so that for those claiming on their 62 nd birthday their benefits are $80 \%$ of what they would be if they waited until the normal retirement age. The size of the reduction factor will be only $5 / 12$ of one percent for months beyond 36 months before the NRA, which will become relevant once the delay in NRA becomes effective. The reduction is called the Actuarial Reduction Factor. Individuals can also delay the receipt of benefits beyond age 65 , and receive a Delayed Retirement Credit (DRC). For workers reaching age 65 in 1996, an additional $5 \%$ is paid for each year of delayed receipt of benefits. Under current legislation this amount will steadily increase until it reaches 8\% per year in 2009 .

While one can claim as early as age 62 , receipt of SS benefits is conditioned on the "earnings test" until the worker reaches age 70: if one earns more than a certain floor level, SS benefits are reduced for each additional dollar of earnings, until at high earnings levels one cannot qualify at all. In order to receive all of his or her benefits, in 1995 a worker must have earnings below $\$ 8280$ if between 62 and 65 , and below $\$ 12,500$, if between 65 and 70 . These figures increase each year 
with average earnings in the economy. Benefits are reduced for any earnings above this limit, $\$ 1$ for each $\$ 2$ of earnings for workers between 62 and 65 and $\$ 1$ for every $\$ 3$ for workers between 65 and 70. There is a special monthly retirement test for workers in their first year of retirement. In 1996 legislation, the earnings limit for those between 65 and 69 has been increased in a series of steps, reaching $\$ 30,000$ in 2002 . Months of benefits lost through the earnings test treated as delayed receipt, entitling the worker to a delayed retirement credit on the lost benefits when he does claim benefits.

There are also important additional benefits provisions based on family structure. Spouses of SS beneficiaries receive an additional benefit which is $50 \%$ of the PIA, beginning at age 62 , although a spouse only receives the larger of this and her own entitlement as a worker. ${ }^{9}$ Dependent children are also each eligible for $50 \%$ of the PIA, but the total family benefit cannot exceed a maximum which varies with PIA level but is roughly $175 \%$ of the PIA. Surviving spouses receive $100 \%$ of the PIA, beginning at age 60 , although there is an actuarial reduction for claiming widow benefits before age 65 or if the worker had an actuarial reduction. The benefits for dependents are somewhat complicated by the fact that both spouses may qualify for SS benefits as retired workers. For previous generations, where wives generally earned substantially less over their lifetimes than their husbands, this was not such an important consideration. But in recent times it is quite frequent that wives will earn enough so that they would have a PIA of at least half of that of their husbands, so that they will not automatically use the default of dependents benefits; benefits are the maximum receivable under different provisions. Currently, of the 20 million female beneficiaries of SS, 7.5 million are entitled solely as workers, 5 million are entitled both as workers and as dependents/survivors, and another 7.5 million are entitled solely as dependents or survivors.

\footnotetext{
${ }^{9}$ Spousal benefits can begin earlier if there is a dependent child in the household.
} 
Benefit payments are adjusted for increases in the Consumer Price Index (CPI) after the worker has reached age 62 . Thus, Social Security provides a real annuity to its recipients. SS benefits are largely tax favored: they are only taxed if the sum of other income and one-half of SS benefits exceed $\$ 32,000$ for a joint return, and even at that point they are only partially taxed.

Finally, it is important to note that the SS program does not operate in a vacuum. There are a number of other public assistance programs for which elderly persons are eligible which may also have effects on their labor market behavior. One such program is Disability Insurance, which provides income insurance to workers physically unable to participate in the labor force. Given the difficulty of distinguishing true career-ending disability, particularly in the near-elderly population, this program also potentially has an effect on the retirement decisions of older workers. Indeed, there is a large empirical literature in recent years which suggests that variations in DI program parameters do affect labor force participation among those age $45-65 .^{10}$

Moreover, there is an important interaction between DI and SS. As noted above, if individuals receive SS benefits before the normal retirement age of 65 , they are reduced by $5 / 9$ of one percent per month. However, if an individual with the same earnings trajectory qualifies for DI, then they receive their full SS entitlement with no reduction. ${ }^{11}$ It is unclear how substitutable SS early retirement and DI are, but this potentially reduces any savings to the government from lowering the benefits for early retirement, or raising the age of early eligibility, without changing the benefit structure for disabled workers. This is highlighted by Figure 9 , which showed the interaction between the rise in SS recipiency and the decline in DI recipiency around age 62 .

\footnotetext{
${ }^{10}$ See for example Bound (1989, 1991); Gruber (1996); Gruber and Kubik (forthcoming); Leonard (1986); Parsons (1980, 1991a,b).

"This calculation is complicated, of course, by the fact that additional work can affect the benefits computation.
} 
Another public assistance program which potentially interacts with SS is the Supplemental Security Income (SSI) program, which provides income support to low income elderly (defined as at least 65) and disabled individuals. Unlike SS or DI, benefits and eligibility for SSI are conditioned on point in time income, rather than lifetime income. The size of the SSI recipient population is small relative to SS recipients; fewer than $4 \%$ of SS recipients age 65 and older also receive SSI. On the other hand, over $2 / 3$ of SSI recipients do receive some SS income. So SSI is serving both as an alternative to SS for very low income elderly, and as a supplement for those with very low SS income.

There are also large private incentives for retirement embedded in firm pension plans. Pension coverage has grown dramatically in the post-war period, and in 1994 roughly $45 \%$ of workers age 21 to 65 were covered by a pension plan at work. ${ }^{12}$ Given the age structure in the pattern of job-holding relative to pension provision, a noticeably larger fraction of workers are covered by pension provisions at some time in their careers than this number suggests. On the other hand, some fraction of workers cash out their pension accumulations when changing jobs, leaving no accumulation when reaching retirement. In 1994, 35\% of retired workers over age 62 who were receiving Social Security were receiving pension income as well. A number of papers in recent years have suggested that pension incentives play an important role in determining retirement behavior among covered workers; this may interact with the SS incentives described below. ${ }^{13}$

Finally, for understanding the role of SS it is important to consider this program in the broader context of the treatment of older workers in the labor force. The U.S. has a broad set of protections in place for the rights of older workers through the 1967 Age Discrimination in

\footnotetext{
${ }^{12}$ Authors' tabulations from March 1995 Current Population Survey.

${ }^{13}$ See Stock and Wise (1988) or Samwick (1993).
} 
Employment Act, including legal restrictions on age-of-hire rules and on mandatory retirement (Parsons, 1996). This levels the playing field between older and younger workers for labor supply decision-making, highlighting the potential importance for retirement decisions of financial incentives such as those through SS.

\section{The Retirement Effects of SS - Theory and Evidence}

There is a large U.S.-based literature which describes both the expected effects of the SS system on retirement and evidence on the actual retirement impacts of the program. The motivation for examining the effects of SS can be seen clearly by examining the hazard rate out of the labor force for men and women. This is measured as the increase in the rate of labor force leaving from the previous age, relative to the stock of workers participating at the previous age. Figure 12 shows the hazard rate for labor force leaving for men. The striking fact about this figure is the dramatic increase in labor force leaving at age 62 , which is the age of eligibility for early retirement under Social Security, and at age 65 , which is the normal retirement age. These spikes are very suggestive of a role for SS in explaining the retirement behavior of men. There is also a small spike around age 55, which may reflect the early retirement provisions at that age under many pension plans. There is also another spike around age 68; the cause here is not clear, although the small denominator of the participation hazard after age 65 makes it hard to interpret this finding. ${ }^{14}$

These hazard for women is plotted in Figure 13. The spike at age 65 is apparent here as well, but the spike at age 62 is not as pronounced. This may reflect the fact that female retirement is determined more by joint timing with husbands than by SS incentives.

${ }^{14}$ That is, the spike at age 65 represents a 9.5 percentage point change in labor force participation, while the spike at age 68 represents only a 4.5 percentage point change; the latter appears almost as large as the former because the denominator is so much smaller. 
In Appendix I, we discuss theoretically the various effects that SS has on retirement behavior, and then review the extensive U.S.-based literature on SS and retirement. We highlight the sources of agreement and disagreement in the existing literature, and conclude that there is fairly broad agreement that the overall structure of SS is an important determinant of retirement, even while there remains disagreement over the effects of variations in program generosity within this structure.

\section{Part III: Retirement Incentives}

In this section, we use a model of SS benefits determination to assess the incentives of SS on retirement through accrual rate effects.

\section{Simulation Modelling}

The basis for our analysis is the Social Security Administration's ANYPIA program. ${ }^{15}$ This program inputs a set of worker characteristics: age, wife's age, earnings history, and date of retirement. It then computes the benefits entitlement for a given month in the future. To do so, we use the Social Security base case assumptions about price and wage growth in the future. The program computes the benefits for the worker, dependent benefits for married workers, and survivor benefits for the case where the worker has died.

The next step in our simulation is to take these monthly benefit entitlements and compute an expected net present discounted value of Social Security Wealth (SSW). This requires projecting benefits out until workers reach age 100 , and then taking a weighted sum which discounts future benefits by both the individual discount rate, and the prospects that the worker will live to a given

\footnotetext{
${ }^{15}$ We are grateful to Steve McKay of the Social Security Administration for his assistance in applying this program to our purposes.
} 
future age ${ }^{16}$ Our methodology for doing so is described in Appendix I. For the worker himself, this is fairly straightforward; it is simply a sum of future benefits, discounted backwards by time preference rates and mortality rates. For dependent and survivor benefits, it is more complicated, since we must account for the joint likelihood of survival of the worker and the dependent. In our base case, we use a real discount rate of $3 \%$, although we will vary this below. To adjust for mortality prospects, we use the sex/age specific U.S. life tables from U.S. Department of Health and Human Services (1990). Finally, to compute net SSW, we subtract out SS payroll tax payments that the individual would make during any continued work. We add both the employee and employer shares of the payroll tax, under the assumption that the employer share if fully borne by the worker in the form of lower wages. All figures are discounted back to age 55 by both time preference rates and mortality risk.

For the output of the simulations, we calculate three different concepts. The first is the net of tax replacement rate, the rate at which SS replaces the (after-tax) earnings of the worker should he continue working in that year. It is important to do this calculation on an after-tax basis, to account for the fact that SS benefits are not taxed for most families, while earnings are. We do so by modelling the average tax rate faced by earners of different earnings level in each year, and whether they are subject to taxation of their SS benefits. The second concept is the accrual rate, the percentage change in SSW from the previous year.

Finally, we compute a tax/subsidy rate, which is the absolute change in SSW over the potential earnings from working that next year. This represents the implicit tax on, or subsidy to continued work, in terms of the net change in SSW that is implied by that additional year of work.

\footnotetext{
${ }^{16}$ We have experimented with extending the model to account for ages up to 120 , since this is the extent of the life table information available. This had little effect on the results, however, since so few persons are alive beyond age 100 .
} 
The numerator of this tax/subsidy rate is the opposite of the change in SSW from working the additional year. The denominator is the potential earnings over that additional year. Thus, if this figure is positive, it implies that the SS system causes a disincentive to additional work through foregone SSW. This is the relevant concept for the worker who is trading off leisure (on SS) against continued work.

Note that in computing these concepts we use the unconditional mortality risk beyond age 55; that is, there is some probability that the worker may be dead at each year after his 55 th birthday. An alternative approach would be to use conditional life tables at each year, so that for the worker considering retiring on his 63 rd birthday we discount the future by the age 63-conditional life table. The correct approach here depends on the perspective from which this computation is taken. Our approach is appropriate if the computation is taken from the perspective of the forward looking 54 year old, who is considering the retirement incentives at all future ages. The alternative would be appropriate for year-by-year decision-making on retirement. Since we discount all of our dollar figures back to age 55 by both time preference and mortality risk, both concepts yield the same tax/subsidy effects (since both numerator and denominator are deflated); however, they will yield somewhat different values of SSW and therefore different accrual rates.

For the purposes of the simulations below, we assume that workers claim SS benefits at the point of their retirement, or when they become eligible if they retire before the point of eligibility. In fact, this is not necessarily true; retirement and claiming are two distinct events, and for certain values of mortality prospects and discount rates it is optimal to delay claiming until some time after retirement (due to the actuarial adjustment of benefits). In fact, a non-trivial share of individuals who retire before age 62 delay claiming their benefits for at least one year. We plan to explore this issue further in future work. 
To produce our base case numbers, we use a typical individual who was born in January, 1935, and thus turned 65 in January, 1995. In theory, to calculate benefits for a worker we would need his entire earnings history. In practice, we use a "synthetic" earnings history which uses the median earnings of a cohort through time. As a first step in creating this synthetic earnings history, we use information on the median earnings by calendar year and age cohort from U.S. Department of Health and Human Services (various years). More specifically, we use the median earnings of a 61 year old in 1991 (the last available year of data) as our base point, and then follow this cohort back through time (using the median for 60 year olds in 1990,59 year olds in 1989 , and so on). We then update this to ages beyond age 61 by using the age-earnings profile for 1991 , along with actual inflation data and base case inflation assumptions.

In pursuing this calculation, we found a relatively steep decline in median earnings after about age 50 , which presumably reflects the fact that more and more of the earning population is working only part-time. However, our synthetic individual is considering the decision to work full-time for an additional year, so this skews the true nature of the underlying earnings history. As a result, we use this synthetic earnings profile through age 50 , and then assume that earnings stay constant in real terms from age 51 onwards.

We assume initially that the worker's wife is exactly three years younger than he. We also assume that she has never worked, so that she claims as a dependent spouse only and not as a worker as well.

\section{Base Case Results}

Table 1 shows our base case results. Each row represents the age of the worker in the last year that they work; that is, the first row represents the effect of working during the 54th year and 
retiring on the 55 th birthday (January 1,1985 ). The first column shows the net replacement rate. This concept is not defined until the worker can actually claim benefits, which occurs if his last year of work is at age 61 so that he retires at 62 .

At that first point of possible claiming, the replacement rate is roughly $40 \%{ }^{17}$ This rises somewhat over time, as workers increase their SS benefits by delaying claiming. The major change occurs for retirement on the 65 th birthday, when the wife turns 62 , since at that point the spouse becomes entitled to dependent benefits. This jump in replacement rates is somewhat artificial, in that the worker who retires at 62 will also see a jump at his 65 th birthday, when his wife turns 62 . That is, the replacement rate rises at age 65 regardless of the age of retirement. For the worker who works through his 69th year and collects on his 70th birthday, SS replaces almost $90 \%$ of his aftertax earnings.

The next three columns show the evolution of SSW over time. For understanding these results, it is useful to recap the four mechanisms through which additional work affects the computation of SSW:

1) The worker must pay SS taxes on his earnings, lowering net SSW

2) The additional year of earnings is used in the recomputation of SS benefits. For workers who have not yet worked 35 years, this additional year will be replacing a zero in the henefits computation; for workers who have worked 35 years, it will potentially be replacing a previous low earnings year. For both of these reasons, additional work raises net SSW.

3) The additional year of work, for work at ages 62 and beyond, implies a delay in claiming. This raises future benefits through the actuarial adjustment, but it implies fewer years over which benefits can be claimed. As a result, there is an ambiguous effect on net SSW.

4) For each year into the future we consider, there is some chance that the worker will die, lowering his net SSW. This is related to (3); the probability of mortality raises the required actuarial adjustment to make the worker indifferent to delayed claiming.

\footnotetext{
${ }^{17}$ This is lower than the replacement rates under Figure 5, since our base case worker has higher earnings than the "average" worker used in that figure.
} 
Thus, it is unclear ex ante whether the SS system will tax or subsidize additional work in any given case.

As Table 1 shows, a worker who retires on his 55th birthday has accumulated roughly $\$ 110,000$ in SSW. There is then a small increase in SSW for work during the 55 th year; this is because that next year "completes" the workers earnings history, with that year of earnings therefore replacing a zero in the benefits computation. After this point, additional earnings only affect the benefits computation to the extent that they replace earlier, lower earnings, years. With a more variable earnings history, as we show below, this "completion" effect will lower tax rates at older ages as well.

For work in the 56th to 61 st year, the SSW uniformly declines. This decline is driven by two factors: the fact that the worker has some (small) chance of dying; ${ }^{18}$ and, more importantly, the fact that the worker is paying the SS payroll tax if he continues to work. As a result, the accrual rate is negative; there is roughly a $1-1.2 \%$ decline in SSW each year from continued work.

The final column shows the tax/subsidy rate. There is a slight subsidy to work in the 55 th year, as noted above, and then taxes on work in the 56th through 61 st years. This tax, however, is lower than the statuatory SS payroll tax rate. This differential arises because these additional years of earnings are replacing lower earnings years in the benefits computation. Thus, there is some tax/benefit linkage in this age range.

There is then a slight subsidy to work during the 62 nd year. This subsidy arises because the worker receives an actuarial adjustment for delaying claiming benefits, which offsets both the payroll tax and the fact that the worker is claiming one year later. That is, for work during the 62nd year,

\footnotetext{
${ }^{18}$ That is, since we discount mortality from the perspective of age 55 , a worker who is considering retiring at age 56 relative to age 57 has a slightly higher chance of receiving his benefits, increasing the SSW.
} 
the system is roughly actuarially "fair". ${ }^{19}$ The fact that the tax rate on continued work actually declines at age 62, while retirement jumps up at that age (Figure 12), is striking, and casts some doubt on the full rationality/perfect markets model often used to explain the effects of SS on retirement. The spike at 62 is more likely associated with either the market imperfections or individual irrationalities discussed in the theory section of Appendix II.

During the 63rd year, the actuarial adjustment is roughly sufficient to compensate for the taxes paid and the smaller number of years of collecting benefits, and there is a no net tax or subsidy. There is then a nontrivial tax rate in the 64th year. For work during the 65 th year, the tax rate jumps up dramatically. For this worker, working during his 65 th year means forgoing over $\$ 2450$ in SSW, which amounts to almost $19 \%$ of what he would earn during that year. This is because the DRC is actuarially unfair, given the foregone year of SS benefits. This tax rate rises further with age, so that for the decision to work during the 70th year, the foregone SSW amounts to almost half of what he would earn during that year. There is an explicit jump for work in the 68th year, due to spousal claiming behavior. For the spouse, as for the worker, there is a penalty to delaying claiming past age 65 . Since we assume that both the worker and his spouse claim when the worker retires, then his working during his 68th year means that his spouse will not claim until after age 65 , and so she will be penalized. It is important to note, however, that future changes in the DRC put in place by the 1983 legislation substantially lowers these work disincentives.

\section{Other Cases}

Table 2 explores these same results for a single worker. In this case, there are slightly

\footnotetext{
${ }^{19}$ Actuarial fairness here refers to the net of taxes and benefits, not to the structure of benefits only.
} 
higher tax rates before the 62 nd year. This is for two reasons. First, in the married case, if the worker dies his wife will still get survivor benefits, so that the discounting for mortality is not as severe as it is for the single worker. Second, the gains from benefits recomputation are smaller for the single worker, since higher benefits affect only him and not both he and his spouse. That is, recomputing benefits for the married worker has a much larger effect both because each additional dollar of benefits turns into an additional $\$ 1.50$ through the spousal benefit, and because that extra dollar becomes an extra dollar of benefits to the surviving spouse as well. Yet, both the married and single worker pay the same payroll tax, so this results in a larger net disincentive for the single worker.

Interestingly, for the single worker this disincentive does not diminish noticeably for work during the 62 nd year. Here, the system is actuarially unfair; the extra benefits in future years from delaying claiming are outweighed by the foregone year of claiming and the taxes paid. So, for work during ages 62-67, the system offers much larger disincentives to single than to married workers; by age 67 , the implicit tax rate is over $40 \%$. On the other hand, for work during ages 68 and 69 , the tax rate is actually lower for single workers, due to the unfairness of the DRC for both spouses in the married worker case (as described above).

Tables 3 and 4 consider the effect of considering different earnings histories, for a married worker. We consider two additional cases: that of a worker at the 10th percentile of the earnings distribution; and that of a worker at the 90th percentile of the distribution. Since we do not have true longitudinal data, we assume that the age/earnings profile is the same at the 10th and 90th percentiles as at the median, and just use data on the 1995 differences across these percentiles to scale the profiles up and down.

These changes have important effects on the retirement incentives inherent in SS. As the first 
column of Table 3 shows, the replacement rate is much higher for the low earnings worker, confirming the findings of Figure 5. The time pattern of tax/subsidy rates across earnings groups are also shown in Figure 14. Before age 62, there is a somewhat higher tax rate on high wage workers, since the tax/benefit linkage is reduced by the redistributive nature of benefits computation. From age 62-64, there is a large subsidy to continued work after age 61 for the low earnings workers, while there is a tax on the high earners. This reflects the fact that the low earnings workers are getting a much higher return from their SS contributions at this age. This pattern reverses from age 65 onwards, however, as the large negative accruals implicit in SS at older ages are much larger on the smaller base of earnings at the 10th percentile. By age 69 , the implicit tax rate on low earnings workers is over twice that on high earners.

Table 5 considers a different permutation to the earnings history: assuming that the worker who didn't start work until 1929 , so that he has an incomplete earnings history (less than 35 years of work) until he works during his 63rd year. This has a striking effect on the incentives before age

64. In the place of sizeable tax rates on continued work before age 62 , there are now small subsidies; and in the place of a small subsidy at age 62 , there is now a much larger subsidy. That is, for a worker with this incomplete earnings history, working during their 62 nd year receives a subsidy of $15 \%$, due to the value of replacing a zero in their average monthly earnings computation. Once this worker reaches age 64 , however, the incentives are almost identical to those for the base case, since the earnings history has been completed.

\section{Part V: Conclusions}

The Social Security program is an important feature of the opportunity set of workers making their retirement decisions. There is clear evidence from both previous work and hazard rate 
diagrams that the broad structure of the SS program influences retirement timing. Evidence on the effects of variation in the benefits provided by this program is less clear, however. In this paper, we have explicitly documented the implicit tax rates on continued work from this system. We find that, on average for married men with non-earning spouses, there is little net tax on continued work around the age of early eligibility for SS, but that the tax becomes quite large at the normal retirement age. There is important heterogeneity in these incentives across workers, however, according to features such as marital status and earnings.

The implications of these findings depend critically on the elasticity of response of retirement behavior to the implicit tax rates of the SS program. As we have noted, this elasticity remains a source of empirical controversy. Future work in this area could employ recent high quality data on SS entitlements and retirement behavior to resolve this controversy. 


\section{Appendix I: Data Sources}

\section{Historical Data:}

1) Labor Force Participation by age and sex (Figures 1 and 2): U.S. Bureau of Labor Statistics (various years).

2) Share of Workers Covered and Replacement Rates (Figures 3 and 5): U.S. Congress Committee on Ways and Means (1993).

3) Recipiency of SS/DI by age and sex (Figure 4) and median earnings by cohort over time (simulations): U.S. Department of Health and Human Services (1995)

\section{Contemporaneous Data}

All contemporaneous figures tabulated by Author from March CPS data for 1994 and 1995

\section{Studying Retirement in the U.S.}

There are two types of data available for studying retirement in the U.S.:

1) Cross-sectional data on participation at a point in time. The CPS is one of a variety of crosssectional surveys available. Another of note is the National Health Interview Survey (NHIS), which also has health information.

2) Longitudinal data which follows individuals over time, providing information on demographics, labor force attachment, and income sources. Some examples here are:

a) The Survey of Income and Program Participation (SIPP: 1984-present), which follows a large sample of persons over a period of 2-3 years.

b) The Panel Study of Income Dynamics (PSID: 1968-present), which has followed a smaller sample of persons since 1968 .

c) The Retirement History Survey (RHS: 1969-1979) and National Longitudinal Surveys of Older Men and Women (NLS: 1968-present), which follow large samples of older persons over time; the former survey has detailed information on the workers entire earnings history.

d) The Health and Retirement Survey (HRS: 1992-present), which updates the RHS with a new cohort of older persons that will be followed for at least 10 years. This survey has the richest data yet available on a retirement survey, including detailed information on earnings histories and firm pension plans. 


\section{Appendix II: The Effect of SS on Retirement - Theory and Evidence}

\section{Theory}

The major role that SS plays in determining the well-being of the elderly, as well as the dramatic spikes in labor force participation and retirement at exactly the ages of SS entitlement in Figures 12-13, suggest that SS is a key determinant of retirement behavior. But in practice it is quite complicated to model the effects of SS on retirement. In this section, we provide an overview of the effects of the system on retirement. This discussion draws heavily on Crawford and Lilien (1981); for a related discussion, see Burtless and Moffitt (1986).

The discussion proceeds in three steps. First we consider the effects of SS on retirement in a perfect market/full rationality setting. Then we examine the implications of effects coming from imperfections in the credit and insurance markets. Finally, we consider the implications of behavioral responses that do not correspond to the full rationality model.

In a full rationality/perfect markets setting, one has two types of effects of social security on retirement: income effects and substitution effects. Insofar as the system increases the lifetime wealth of an individual it will tend to induce earlier retirement (assuming that leisure is a normal good). Such redistributions happen across generations, particularly from the large benefits coming with an underfunded pay-as-you-go system. Such redistributions also happens within a generation, reflecting both deliberate redistributions and the redistributional effects of other policies. For example, the progressivity in the benefit formula is a redistribution to lower earners, for a given life expectancy (although life expectancy does vary systematically with income level). The presence of spouse benefits represents a redistribution from the never married to couples with different earnings histories. The use of an approach based on giving a maximum of an earned benefit and a spouse or surviving spouse benefit redistributes among couples, giving more to couples that have very 
different earnings levels, particularly one earner couples. The presence of child benefits helps those having children late in life (so they are still young when the worker retires). Since benefits are paid as an annuity, with the same formula for all, the system redistributes toward those who, ex ante, have greater life expectancies. There are similar effects from the DI portion of the program. In terms of substitution effects, one needs to consider the financial implications of continuing work once eligible for retirement benefits, as documented above.

Once one moves away from a perfect market setting, one can not infer the effects of social security solely from their implications for the shape of the lifetime budget constraint. There are two effects that have been recognized in the literature. Insofar as it is difficult to borrow against future earnings, some young workers will be liquidity constrained, consuming less than they would if they could borrow against future earnings. The payroll tax tightens this constraint resulting in even lower consumption among such workers. As a result of having consumed less when young, these workers may have more wealth when reaching retirement age, resulting in an income effect leading to earlier retirement.

With imperfect individual annuity markets, SS is providing real annuities that are not available in the market. Correction of this market failure has two effects. One is that the greater efficiency in planning lifetime consumption associated with annuitization works like an income effect, resulting in earlier retirement. Second, the link between work and the size of these annuities is an incentive for additional work at retirement age. Moreover, the inability to tap this source of wealth until reaching the early retirement age will lead some people to continue to work until retirement age who would otherwise have chosen to retire before this age.

Turning to individual irrationalities, it is a premise of SS systems that many individuals would not save enough to finance their retirements in the absence of compulsion. Forcing people to save 
more than they would (myopically) choose to results in greater wealth at retirement age and so an income effect leading to earlier retirement. Also relevant is the possibility of myopia in making the retirement decision itself, based on evaluating only the consumption possibilities in the near term rather than over the full remaining life span. This might result in some people retiring too soon. ${ }^{20}$ Limiting eligibility until the early retirement age reduces this effect.

A further element comes into focus once one considers a couple. Poverty rates among widows are roughly three times as high as among married women of the same age. This suggests that many couples are not choosing sizeable joint life annuitization. Insofar as SS requires partial joint life annuitization that would not have been chosen by the couple, it lowers consumption of the workers at retirement age and may lead to more work.

\section{Evidence}

There is an enormous empirical literature which attempts to evaluate the effects that SS has had on retirement behavior. There are two broad strands of this literature. The first uses aggregate information on the labor force behavior of workers at different ages over time to infer the role that is played by Social Security. Hurd (1990) and Ruhm (1994) emphasize the spike in the age pattern of retirement at age 62; as Hurd (1990) states, "there are no other institutional or economic reasons for the peak". Moreover, both authors show that this peak has grown over time, as SS generosity has increased; and Burtless and Moffitt (1986) show that this peak was not present in 1960, before this early retirement option was available. As Ruhm (1994) notes, however, the existence of this

\footnotetext{
${ }^{20}$ One must be careful here in measuring the degree of rationality about retirement decisions. For example, from the perspective of maximizing family SS wealth, a given husband may appear to retire too early. However, if he downweights his wife's consumption in his utility function, his decision may be individually rational.
} 
peak does not prove that SS is lowering participation rates among all older workers; in fact, it may be inducing longer work among those age 60 and 61 in order to qualify for early retirement at age 62.

Moreover, for workers for whom the actuarial adjustment, additional tax, and AIME recomputation is fair on average, there is no reason for SS per se to induce a spike at age 62; it is only an interaction of SS with liquidity constraints that would yield this response. Indeed, this is exactly what Kahn (1988) finds; there is a spike in retirement at age 62 for low wealth workers, but not for very high wealth workers.

There is also a large spike in retirement at age 65 , as noted by many analysts, which would be consistent with the traditionally unfair actuarial adjustment by Social Security for additional work beyond age 65 . Indeed, using more precise quarterly data, Blau (1994) finds that almost one-quarter of the men remaining in the labor force at their 65 th birthday retire within the next three months; this hazard rate is over 2.5 times as large as the rate in surrounding quarters. However, Lumsdaine, Stock, and Wise document that this penalty alone cannot account for this "excess" retirement at age 65; nor can the incentives embedded in private pension plans or the availability of retirement health insurance through the Medicare program. This does not rule out a role for Social Security here; by setting up the "focal point" of a normal retirement age, the program may be the causal factor in explaining this spike.

The second strand of this literature attempts to specifically model the role that potential SS benefits play in determining retirement. The general strategy followed by this literature is to use micro-data sets with information on potential SS benefit determinants (earnings histories) or ex-post 
benefit levels to measure the incentives to retire across individuals in the data. ${ }^{21}$ Then, retirement models are estimated as a function of these incentive measures. While the exact modelling technique differs substantially across papers, ${ }^{22}$ the conclusions drawn are fairly similar: SS has large effects on retirement, but they are small relative to the trends over time documented in Figures 1 and 2 . For example, Burtless (1986) found that the 20\% benefit rise of the 1969 to 1972 period raised the probability of retirement at 62 and 65 by about 2 percentage points. Over this period, however, the labor force participation of older men fell by over $6 \%$, so that SS can only explain about $1 / 3$ of the change. ${ }^{23}$

This literature suffers from two important limitations. First, the key regressor, Social Security benefits, is a non-linear function of past earnings, and retirement propensities are clearly correlated with past earnings levels. This problem is common to the social insurance literature in the U.S. ${ }^{24}$ But for other social insurance programs there is often variation along dimensions arguably exogenous to individual tastes, such as different legislative regimes across locations or within locations over time, that can be used to identify behavioral models. There is no comparable

\footnotetext{
${ }^{21}$ The data used are generally the Retirement History Survey (Boskin and Hurd, 1978; Burtless, 1986; Burtless and Moffitt, 1984; Hurd and Boskin, 1984; Fields and Mitchell, 1984; Blau, 1994), although some authors have relied on the National Longitudinal Survey of Older Men (Diamond and Hausman, 1984), and recent work uses the Survey of Consumer Finances (Samwick, 1993).

${ }^{22}$ The earliest studies (Boskin and Hurd, 1978; Fields and Mitchell, 1984) used standard linear or non-linear regression techniques. Later research (Burtless, 1986; Burtless and Moffitt, 1984) used non-linear budget constraint estimation to capture the richness of Social Security's effects on the opportunity set. The most recent work (Diamond and Hausman, 1984; Hausman and Wise, 1985; Samwick, 1993; Blau, 1994) uses dynamic estimation of the retirement transition.

${ }^{23}$ One exception is Hurd and Boskin (1984), who claim that the large benefits increases of the 1968-1973 period can explain all of the change in labor force participation in those years.

${ }^{24}$ See Meyer (1989) for a careful discussion of this issue in the context of Unemployment Insurance (UI).
} 
variation in Social Security, which is a nationally homogeneous program. Of course, this criticism does not necessarily imply that the estimates of this cross-sectional literature are flawed; as Hurd (1990) emphasizes, the non-linearities in the SS benefits determination process are unlikely to be correlated with retirement propensities. But there has been little serious effort to decompose the sources of variation in SS benefits in an effort to assess whether the determinants that drive retirement behavior are plausibly excluded from a retirement equation. ${ }^{25}$

This criticism is levied most compellingly by Krueger and Pischke (1992), who note that there is a unique "natural experiment" provided by the end of double-indexing for the "notch generation" that retired in the late 1970s and early 1980s. For this cohort, SS benefits were greatly reduced relative to what they would have expected based on the experience of the early-mid 1970s. Yet, the dramatic fall in labor force participation continued unabated in this era. This raises important questions about the identification of this cross-sectional literature.

The second problem with this literature is that it generally focuses on only one of the two key SS benefits variables, including SS benefits or wealth but ignoring the SS tax/subsidy rate documented above. In theory, as discussed above, both of these factors plays an important role in determining retirement behavior. Studies which included this regressor found it to have a significant role in explaining retirement (Fields and Mitchell, 1984; Samwick, 1993); indeed, even in Krueger and Pischke's (1992) paper the accrual rate is often right-signed and significant, even as the wealth

\footnotetext{
${ }^{25}$ At a minimum, one would want to include the level of lifetime earnings as a regressor, but most studies include only earnings in a recent year (ie. Boskin and Hurd, 1978; Burtless, 1986). In addition, even using a somewhat longer time frame for measuring the earnings control (as Diamond and Hausman, 1984, do) does not solve the problem; one could imagine that certain features of the lifetime pattern of earnings are correlated with both benefit levels and retirement decisions, such as the ratio of earnings around age 62 to earnings at earlier ages (since individuals who have relatively high earnings at older ages may have better labor market opportunities around the age of retirement and therefore work longer).
} 
effect is insignificant. More recently, Stock and Wise (1988) noted that the correct regressor for considering both SS and pension incentives for retirement is not the year to year accrual rate, but the return to working this year relative to retiring at some future optimal date. $\quad \mathrm{T} \mathrm{h} \mathrm{u} \mathrm{s,}$ t $\mathrm{o}$ summarize, the past empirical evidence has produced mixed conclusions as to the effect of SS policy on retirement. The abnormal spikes in retirement at the ages of early and normal retirement under SS are suggestive that the structure of the program plays a fundamental role in retirement timing decisions. Within this framework, however, there is only mixed evidence that changes in the overall generosity of the system has much effect on retirement behavior, although the evidence seems clearer for SS accrual rates than for SS wealth levels.

\section{Redistribution}

The other aspect of SS that has been emphasized by previous work is redistribution. Hurd and Shoven (1985), Boskin et al. (1985), and more recently Stuerle and Bakija (1994) document empirically the redistribution within and across generations that we discussed earlier. Table Al presents a summary of the results from Stuerle and Bakija on redistribution across and within generations. Each figure is the expected lifetime net transfer from the SS system, which is total received post-retirement minus taxes paid during the working life. These net transfers are calculated for four demographic groups and for three levels of lifetime earnings, for three dates of retirement. In the first three columns, the expected values use average mortality assumptions; in the last two columns, the authors allow mortality to be income related, accounting for longer lives for higher income individuals. All figures are in thousands of 1993 dollars.

A number of interesting findings emerge from Table A1. First, there is a secular decline in the net transfers from the SS system for newer cohorts; net transfers are positive for all groups 
retiring in 1960 , but negative for most groups for those retiring in 2030 . Second, the system transfers resources differentially to females relative to males, since the tax structure is the same but females live longer. Third, the system transfers resources disproportionately to couples through the spousal and survivor benefits, and even more so to one-earner couples since no taxes are paid by the spouse but he/she gets benefits. Fourth, despite its ostensibly redistributional structure, the system traditionally transferred more resources towards higher income earners than towards lower income earners; this is largely because SS was a good investment and the higher income earners were more heavily invested. But by 1995 , and even more so by 2030 , net transfers are progressive for average mortality prospects. Finally, introducing differential mortality prospects somewhat offsets this progressivity. 
Appendix Table 1: Redistribution Through the SS System Figures are Net Transfers in Thousands of 1993 Dollars

\begin{tabular}{ccccccc}
\hline \hline & \multicolumn{3}{c}{ Average Mortality } & & \multicolumn{2}{c}{$\begin{array}{c}\text { Income-Specific } \\
\text { Mortality }\end{array}$} \\
\cline { 2 - 4 } \cline { 5 - 6 } Wage & 1960 & 1995 & 2030 & & 1995 & 2030 \\
\cline { 2 - 3 } \cline { 5 - 7 } $\begin{array}{c}\text { Single Male: } \\
\text { Low }\end{array}$ & 26.1 & 12.5 & -4.1 & & 5.1 & -13.8 \\
Average & 36.5 & -5.1 & -56.2 & & -5.1 & -56.2 \\
High & 36.8 & -37.1 & -248.5 & & -20.8 & -224.3 \\
Single Female: & & & & & & \\
Low & 41.4 & 33.4 & 22.5 & & 27.0 & 13.0 \\
Average & 59.4 & 28.1 & -13.8 & & 28.1 & -13.8 \\
High & 62.1 & 6.5 & -187.3 & & 20.4 & -162.9 \\
One-Earner Couple: & & & & & \\
Low & 62.3 & 89.5 & 99.3 & & 86.0 & 94.2 \\
Average & 89.9 & 122.5 & 117.0 & & 122.5 & 117.0 \\
High & 97.2 & 134.7 & 24.2 & & 144.6 & 36.2 \\
Two-Earner Couple: & & & & & \\
Low & 68.4 & 62.6 & 36.5 & & 53.1 & 30.0 \\
Average & 88.7 & 78.6 & 29.4 & & 78.6 & 29.4 \\
High & 98.7 & 37.1 & -173.5 & & 53.5 & -154.9 \\
\hline \hline
\end{tabular}

Notes: Figures are from Stuerle and Bakija (1994). 


\section{Appendix III}

In this appendix, we provide the formulae for our computation of SS wealth.

Notation:

$\mathrm{AM}=$ worker's age

AF $=$ spouse's age

$\mathrm{YM}=$ year of worker's birth

YF = year of spouse's birth

$\mathrm{a}=$ month of worker's birth

maxage $=$ maximum potential age that we consider for both worker and spouse

$\rho=$ discount rate

$\mathrm{t}=$ number of months after attainting age 62 that the worker decides to wait before first claiming benefits

$\mathrm{m}=$ number of months after $\mathrm{t}$ that the worker decides to continue working just below the earnings test limit (so that he is still eligible for full benefits, despite continued work)

$\mathbf{s}=$ number of months that a spouse, aged less than normal retirement age, decides to wait until starting to claim benefits.

$\left\{s_{k}\right\}, k=1 \ldots, 12 *$ (maxage-AM) $=$ number of months that a widow aged less than her normal retirement age, and whose partner died $\mathrm{k}$ months after attaining age 62 , decides to wait before claiming her survivor benefits.

$\mathbf{B}_{\mathbf{x}}=$ amount of benefits that the worker is entitled to in month $\mathbf{x}$

$D_{x}=$ amount of benefits that the spouse is entitled to claim in month $x$ on the basis of the worker's earnings history

$\mathrm{C}_{\mathrm{x}}=$ amount of benefits that the surviving spouse is entitled to claim in month $\mathrm{x}$ in case the worker dies (before retiring) in month $x$

$E_{x}=$ amount of benefits that the surviving spouse is entitled to claim in month $x$ in case the worker dies (after retiring) in month $x$

$\theta^{1}{ }_{\mathrm{i}}=$ dummy variable which is 1 if $12 * \mathrm{AF}+\mathrm{k} \geq 12 * 60+\mathrm{s}$, and which is 0 otherwise

$\theta^{2}=$ dummy variable which is 1 if $12 * A F+k \geq 12 * 60+s_{k}$, and which is 0 otherwise

$\mathbf{p}_{\mathbf{x}}(. \mid \mathrm{YM}, \operatorname{sex})=$ cohort and sex specific conditional probability measure expressing the probability that the worker is still alive in month $x$, conditional on being alive in month $x-1$. By definition, $\mathrm{p}_{12^{*} 62}=1$

$q_{x}(. \mid Y M, s e x)=$ cohort and sex specific conditional probability measure expressing the probability that the spouse is still alive in month $x$, conditional on being alive in month $x-1$. By definition, $\mathrm{p}_{12^{*} \mathrm{AF}}=1$

$\mathrm{w}=(12 *(\mathrm{YM}+\mathrm{AM}-1)+\mathrm{a}+\mathrm{i}) / 12$

$\mathrm{v}=(12 *(\mathrm{YM}+\mathrm{AM}-1)+\mathrm{a}+\mathrm{k}) / 12$

$\mathbf{B I}_{\mathrm{x}}=$ increase in benefits in December of year $\mathrm{x}$

$\mathrm{SSC}_{\mathrm{x}}=$ contributions to SS system in month $\mathrm{x}$

$\mathrm{i}, \mathbf{l}, \mathbf{j}, \mathbf{k}$ are simple counting variables

The construct of interest for our analysis is the net present discounted value (NPDV) of SS bneefits. This is the sum of four components: 
PB = NPDV of worker's benefits

SpB = NPDV of spousal benefits

SuB $=$ NPDV of survivor benefits

SSC $=$ NPDV of SS contributions

$$
\begin{aligned}
& P B \equiv \sum_{i=t}^{12 \text { (merage }=A M)}\left\{B_{12 \cdot A M+i} * p_{12 \cdot A M+i}(. \mid Y M, \operatorname{sex}) *(1+\rho)^{-\eta}\right\} \\
& S p B=\sum_{i=t}^{12 \text { (merage }=A F)}\left(D_{12 \cdot 1 M+i} * \theta_{i}^{1} *\left(\prod_{j=0}^{l}\left(q_{12 \cdot A F+j}(. \mid Y F, \operatorname{sex}) * p_{12 \cdot A M+j}(. \mid Y M, \operatorname{sex})\right)\right) *(1+\rho)^{-i}\right\} \\
& S u B \equiv \sum_{k=0}^{t-1}\left\{\sum _ { i = k } ^ { 1 2 \text { (maxage-Af) } } \left\{C_{12 \cdot A M+i} * \theta_{i}^{2} *\left(\prod_{j=0}^{k-1}\left(p_{12 \cdot A M+j}(. \mid Y M, \operatorname{sex})\right)\right)\right.\right. \\
& \left.\left.*\left(1-p_{12: A M+j}(. \mid Y M, \operatorname{sex})\right) *\left(\prod_{j=0}^{j}\left(q_{12: A F+j}(. \mid Y F, \operatorname{sex})\right)\right) * \frac{\left(\prod_{t=v}^{N}\left(1+B I_{p}\right)\right)}{\left(1+B I_{\nu}\right)}\right\}\right\} \\
& +\sum_{k=1}^{12 \text { (maxage-AM) }} 1 \sum_{i=k}^{12 \text { (maxage }-A F)}\left(E_{12 \cdot A M+i} * \theta_{i}^{2} *\left(\prod_{j=0}^{k-l}\left(p_{12 \cdot A M+j}(. \mid M M, \operatorname{sex})\right)\right)\right. \\
& \left.\left.*\left(1-p_{12 \cdot A M+j}(. \mid y M, \operatorname{sex})\right) *\left(\prod_{j=0}^{i}\right)\left(q_{12: A F+j}(. \mid Y F, \operatorname{sex})\right)\right) * \frac{\left(\prod_{l=v}^{w}(1+B I)\right)}{\left(1+B I_{\nu}\right)}\right\} \\
& S S C \equiv \sum_{i=0}^{t+m} S S C_{(12,1 M)+i}
\end{aligned}
$$

The net present discounted value of social security benefits is thus:

$$
N P D V S S C \equiv P B+S p B+S u B+S S C
$$




\section{References}

Blau, David M. (1994). "Labor Force Dynamics of Older Men, " Econometrica, 62, 117-156.

Boskin, Michael J., and Michael D. Hurd (1978). "The Effect of Social Security on Early Retirement," Journal of Public Economics, 10, 361-377.

Boskin, Michael et al. (1987). "Social Security: A Financial Appraisal Across and Within Generations," National Tax Journal 40, 19-33.

Bound, John (1989). "The Health and Earnings of Rejected Disability Insurance Applicants," American Economic Review 79, 482-503.

Bound, John (1991). "The Health and Earnings of Rejected Disability Insurance Applicants: Reply," American Economic Review 81, 1427-1434.

Burtless, Gary (1986). "Social Security, Unanticipated Benefit Increases, and the Timing of Retirement," Review of Economic Studies 53, 781-805.

Burtless, Gary, and Robert Moffitt (1984). "The Effect of Social Security Benefits on the Labor Supply of the Aged," in H. Aaron and G. Burtless, eds., Retirement and Economic Behavior. Washington: Brookings Institution,135-175.

Burtless, Gary, and Robert Moffitt (1986). "Social Security, Earnings Tests, and Age at Retirement, " Public Finance Ouarterly, 14, 3-27.

Crawford, Vincent P., and David M. Lillien (1981). "Social Security and the Retirement Decision," Quarterly Journal of Economics, ????, 505-529.

Diamond, Peter, and Jerry Hausman (1984). "Retirement and Unemployment Behavior of Older Men," in H. Aaron and G. Burtless, eds., Retirement and Economic Behavior. Washington: Brookings Institution, 97-135.

Feldstein, Martin S. and Andrew Samwick (1992). "Social Security Rules and Marginal Tax Rates," National Tax Journal, 45, 1-22.

Fields, Gary S., and Olivia S. Mitchell (1984). Retirement. Pensions, and Social Security. Cambridge, MA: MIT Press.

Gruber, Jonathan (1996). "Disability Insurance Benefits and Labor Supply of Older Persons". Mimeo, MIT.

Gruber, Jonathan, and Jeffrey D. Kubik. "Disability Insurance Rejection Rates and the Labor Supply of Older Workers, " Journal of Public Economics, forthcoming.

Hausman, Jerry, and David Wise (1985). "Social Security, Health Status, and Retirement," in D. Wise, ed., Pensions, Labor, and Individual Choice. Chicago: University of Chicago Press, 
159-192.

Hurd, Michael (1990). "Research on the Elderly: Economic Status, Retirement, and Consumption and Saving," Journal of Economic Literature 28, 565-637.

Hurd, Michael, and Michael Boskin (1984). "The Effect of Social Security on Retirement in the Early 1970s," Ouarterly Journal of Economics 99, 767-790.

Hurd, Michael, and John Shoven (1985). "The Distributional Impact of Social Security," in D. Wise, ed., Pensions, Labor, and Individual Choice. Chicago: University of Chicago Press, 193-221.

Kahn, James A. (1988). "Social Security, Liquidity, and Early Retirement," Journal of Public Economics, 35, 97-117.

Krueger, Alan, and Jorn-Steffen Pischke (1992). "The Effect of Social Security on Labor Supply: A Cohort Analysis of the Notch Generation, "Journal of Labor Economics 10, 412-437.

Leonard, Jonathan S. (1986). "Labor Supply Incentives and the Disincentives for Disabled Persons, " In Disability and the Labor Market: Economic Problems. Policies. and Programs, Ed. Berkowitz, M. and M. A. Hill. Ithaca, NY: ILR Press.

Lumsdaine, Robin, and David Wise (1994). "Aging and Labor Force Participation: A Review of Trends and Explanations," in Y. Noguchi and D. Wise, eds., Aging in the United States and Japan: Economic Trends. Chicago: University of Chicago Press, 7-42.

Meyer, Bruce D. (1989). "A Quasi-Experimental Approach to the Effects of Unemployment Insurance." NBER Working Paper No. 3159. Cambridge, MA: National Bureau of Economic Research.

Parsons, Donald (1980). "The Decline of Male Labor Force Participation," Journal of Political Economy 88, 117-134.

Parsons, Donald (1991a). "The Health and Earnings of Rejected Disability Insurance Applicants: Comment," American Economic Review 81, 1419-1426.

Parsons, Donald (1991b). "Self-Screening in Targeted Public Transfer Programs," Journal of Political Economy, 99, 859-876.

Parsons, Donald (1996). "Retirement Age and Retirement Income: The Role of the Firm," in Eric A. Hanushek and Nancy L. Maritato, eds., Assessing Knowledge of Retirement Behavior. Washington, D.C.: National Academy Press.

Peracchi, Franco, and Finis Welch (1994). "Trends in Labor Force Transitions of Older Men and Women," Journal of Labor Economics, 12, 210-242.

Ruhm, Christopher (1995). "Secular Changes in the Work and Retirement Patterns of Older Men," 
Journal of Human Resources, 30, 362-385.

Samwick, Andrew (1993). "The Joint Effect of Social Security and Pensions on the Timing of Retirement: Some New Evidence, " mimeo, MIT.

Stock, James, and David Wise (1990). "Pensions, the Option Value of Work, and Retirement," Econometrica 58, 1151-1180.

U.S. Bureau of Labor Statistics (various years). Employment and Earnings. Washington, D.C.: BLS.

U.S. Congress, House Committee on Ways and Means (1993). Qverview of Entitlement Programs. Washington, D.C.: U.S. Government Printing Office.

U.S. Department of Health and Human Services (1994). Annual Statistical Supplement to the Social Security Bulletin. Washington, D.C.: Social Security Administation. 
Table 1: Base Case Incentive Calculation

\begin{tabular}{cccccc}
\hline $\begin{array}{c}\text { Last Year of } \\
\text { Work }\end{array}$ & $\begin{array}{c}\text { Replace- } \\
\text { ment rate }\end{array}$ & SSW & Accrual & Accrual Rate & $\begin{array}{c}\text { Tax } \\
\text { Subsidy }\end{array}$ \\
\cline { 2 - 6 } 54 & $\cdot$ & 110574 & 0 & 0 & 0 \\
55 & $\cdot$ & 111033 & 458 & 0.004 & -0.022 \\
56 & $\cdot$ & 110126 & -906 & -0.008 & 0.046 \\
57 & $\cdot$ & 108994 & -1133 & -0.010 & 0.060 \\
58 & $\cdot$ & 107734 & -1259 & -0.012 & 0.069 \\
59 & - & 106474 & -1260 & -0.012 & 0.072 \\
60 & - & 105294 & -1180 & -0.011 & 0.071 \\
61 & 0.403 & 104275 & -1019 & -0.010 & 0.064 \\
62 & $\mathbf{0 . 4 4 0}$ & 104701 & 426 & $\mathbf{0 . 0 0 4}$ & -0.028 \\
63 & 0.476 & 104766 & 65 & 0.001 & -0.005 \\
64 & 0.703 & 104335 & -432 & -0.004 & 0.031 \\
65 & 0.749 & 101882 & -2452 & -0.024 & 0.188 \\
66 & 0.798 & 99109 & -2773 & -0.027 & 0.225 \\
67 & 0.845 & 95964 & -3145 & -0.032 & 0.269 \\
68 & 0.872 & 91131 & -4833 & -0.050 & 0.439 \\
69 & 0.898 & 86412 & -4718 & -0.052 & 0.455 \\
\hline \hline
\end{tabular}


Table 2: Incentive Calculation - Single Worker

\begin{tabular}{cccccc}
\hline \hline $\begin{array}{c}\text { Last Year of } \\
\text { Work }\end{array}$ & $\begin{array}{c}\text { Replace- } \\
\text { ment rate }\end{array}$ & SSW & Accrual & Accrual Rate & $\begin{array}{c}\text { Tax/ } \\
\text { Subsidy }\end{array}$ \\
\cline { 2 - 6 } 54 & $\cdot$ & 60934 & 0 & 0 & 0 \\
55 & $\cdot$ & 60083 & -851 & -0.014 & 0.043 \\
56 & $\cdot$ & 58574 & -1510 & -0.025 & 0.081 \\
57 &. & 57007 & -1567 & -0.027 & 0.087 \\
58 &. & 55366 & -1640 & -0.029 & 0.095 \\
59 & - & 53782 & -1585 & -0.029 & 0.095 \\
60 & - & 52290 & -1492 & -0.028 & 0.094 \\
61 & 0.430 & 50885 & -1405 & -0.027 & 0.093 \\
62 & 0.465 & 49682 & -1203 & -0.024 & 0.083 \\
63 & 0.503 & 47704 & -1978 & -0.040 & 0.143 \\
64 & 0.540 & 45385 & -2319 & -0.049 & 0.177 \\
65 & 0.568 & 41324 & -4061 & -0.089 & 0.327 \\
66 & 0.598 & 37192 & -4132 & -0.100 & 0.352 \\
67 & 0.627 & 32939 & -4253 & -0.114 & 0.385 \\
68 & 0.657 & 28651 & -4288 & -0.130 & 0.412 \\
69 & 0.687 & 24334 & -4317 & -0.151 & 0.442 \\
\hline \hline
\end{tabular}


Table 3: Incentive Calculation - $10^{\text {th }}$ Percentile Married Earners

\begin{tabular}{cccccc}
\hline \hline $\begin{array}{c}\text { Last Year of } \\
\text { Work }\end{array}$ & $\begin{array}{c}\text { Replace- } \\
\text { ment rate }\end{array}$ & SSW & Accrual & Accrual Rate & $\begin{array}{c}\text { Tax } \\
\text { Subsidy }\end{array}$ \\
\cline { 2 - 6 } 54 & $\cdot$ & 60936 & 0 & 0 & 0 \\
55 &. & 61141 & 205 & 0.003 & -0.024 \\
56 &. & 60753 & -389 & -0.006 & 0.049 \\
57 &. & 60329 & -424 & -0.007 & 0.055 \\
58 &. & 59820 & -509 & -0.008 & 0.069 \\
59 &. & 59320 & -499 & -0.008 & 0.071 \\
60 & - & 58866 & -454 & -0.008 & 0.067 \\
61 & 0.530 & 58448 & -418 & -0.007 & 0.065 \\
62 & 0.577 & 58841 & 393 & 0.007 & -0.064 \\
63 & 0.627 & 59310 & 470 & 0.008 & -0.080 \\
64 & 0.926 & 59504 & 194 & 0.003 & -0.035 \\
65 & 0.990 & 58521 & -983 & -0.017 & 0.187 \\
66 & 1.056 & 57331 & -1190 & -0.020 & 0.238 \\
67 & 1.119 & 55232 & -2099 & -0.037 & 0.445 \\
68 & 1.156 & 52234 & -2997 & -0.054 & 0.673 \\
69 & 1.193 & 49465 & -2769 & -0.053 & 0.660 \\
\hline \hline
\end{tabular}


Table 4: Incentive Calculation - $90^{\text {th }}$ Percentile Married Earners

\begin{tabular}{cccccc}
\hline \hline $\begin{array}{c}\text { Last Year of } \\
\text { Work }\end{array}$ & $\begin{array}{c}\text { Replace- } \\
\text { ment rate }\end{array}$ & SSW & Accrual & Accrual Rate & $\begin{array}{c}\text { Tax } \\
\text { Subsidy }\end{array}$ \\
\cline { 2 - 6 } 54 & $\cdot$ & 124421 & 0 & 0 & 0 \\
55 &. & 122647 & -1775 & -0.014 & 0.047 \\
56 & $\cdot$ & 119903 & -2743 & -0.022 & 0.076 \\
57 &. & 117159 & -2745 & -0.023 & 0.078 \\
58 &. & 114309 & -2850 & -0.024 & 0.084 \\
59 &. & 111498 & -2811 & -0.025 & 0.087 \\
60 & - & 108800 & -2698 & -0.024 & 0.087 \\
61 & 0.247 & 106436 & -2364 & -0.022 & 0.081 \\
62 & 0.267 & 105760 & -676 & -0.006 & 0.024 \\
63 & 0.290 & 105362 & -398 & -0.004 & 0.015 \\
64 & 0.432 & 104647 & -715 & -0.007 & 0.028 \\
65 & 0.465 & 101810 & -2837 & -0.027 & 0.117 \\
66 & 0.501 & 98602 & -3209 & -0.032 & 0.140 \\
67 & 0.536 & 95054 & -3548 & -0.036 & 0.165 \\
68 & 0.559 & 89545 & -5508 & -0.058 & 0.272 \\
69 & 0.583 & 84203 & -5343 & -0.060 & 0.281 \\
\hline \hline
\end{tabular}


Table 5: Incentive Calculation - Incomplete Earnings History for Married Workers

\begin{tabular}{cccccc}
\hline $\begin{array}{c}\text { Last Year of } \\
\text { Work }\end{array}$ & $\begin{array}{c}\text { Replace- } \\
\text { ment rate }\end{array}$ & SSW & Accrual & Accrual Rate & $\begin{array}{c}\text { Tax } \\
\text { Subsidy }\end{array}$ \\
\cline { 2 - 6 } 54 & $\cdot$ & 97300 & 0 & 0 & 0 \\
55 &. & 97776 & 476 & 0.005 & -0.023 \\
56 &. & 98274 & 498 & 0.005 & -0.025 \\
57 &. & 98635 & 362 & 0.004 & -0.019 \\
58 &. & 98922 & 287 & 0.003 & -0.016 \\
59 &. & 99303 & 380 & 0.004 & -0.022 \\
60 & - & 99732 & 429 & 0.004 & -0.026 \\
61 & 0.391 & 100419 & 687 & 0.007 & -0.043 \\
62 & 0.434 & 102617 & 2198 & 0.022 & -0.145 \\
63 & 0.476 & 104280 & 1662 & 0.016 & -0.115 \\
64 & 0.703 & 103848 & -432 & -0.004 & 0.031 \\
65 & 0.749 & 101395 & -2452 & -0.024 & 0.188 \\
66 & 0.798 & 98622 & -2773 & -0.027 & 0.225 \\
67 & 0.845 & 95477 & -3145 & -0.032 & 0.269 \\
68 & 0.872 & 90644 & -4833 & -0.051 & 0.439 \\
69 & 0.898 & 85926 & -4718 & -0.052 & 0.455 \\
\hline \hline
\end{tabular}




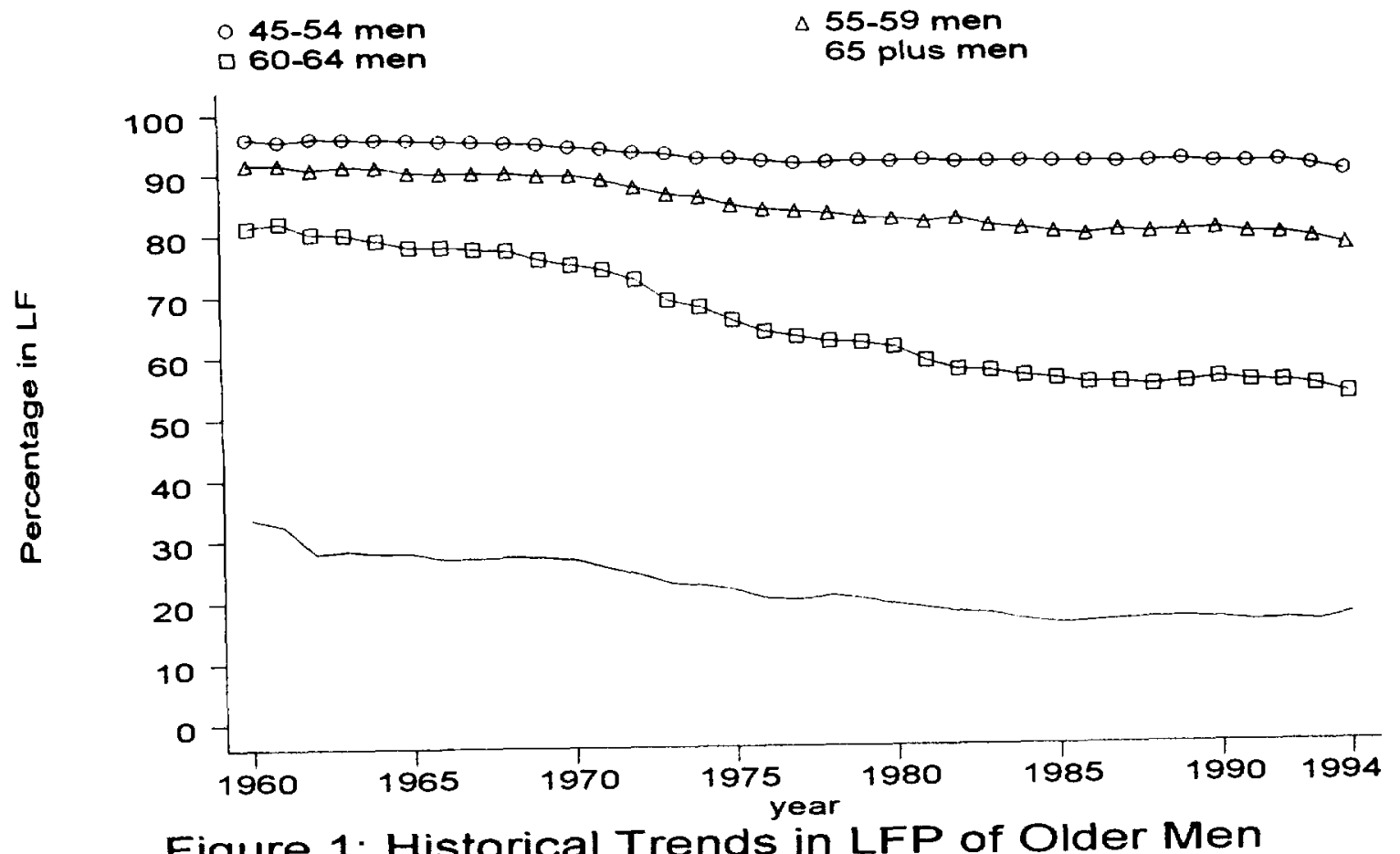

Figure 1: Historical Trends in LFP of Older Men 


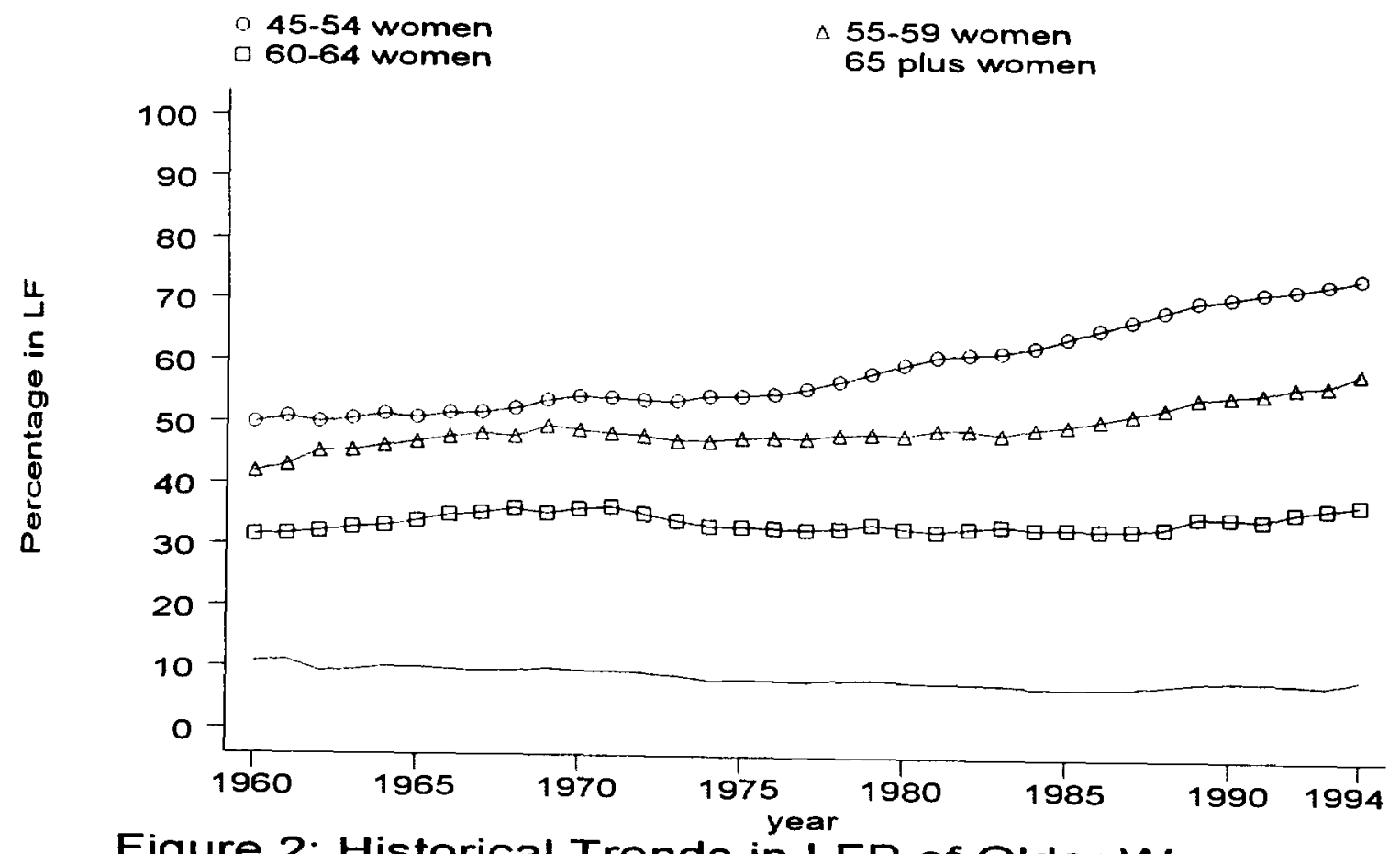

Figure 2: Historical Trends in LFP of Older Women 


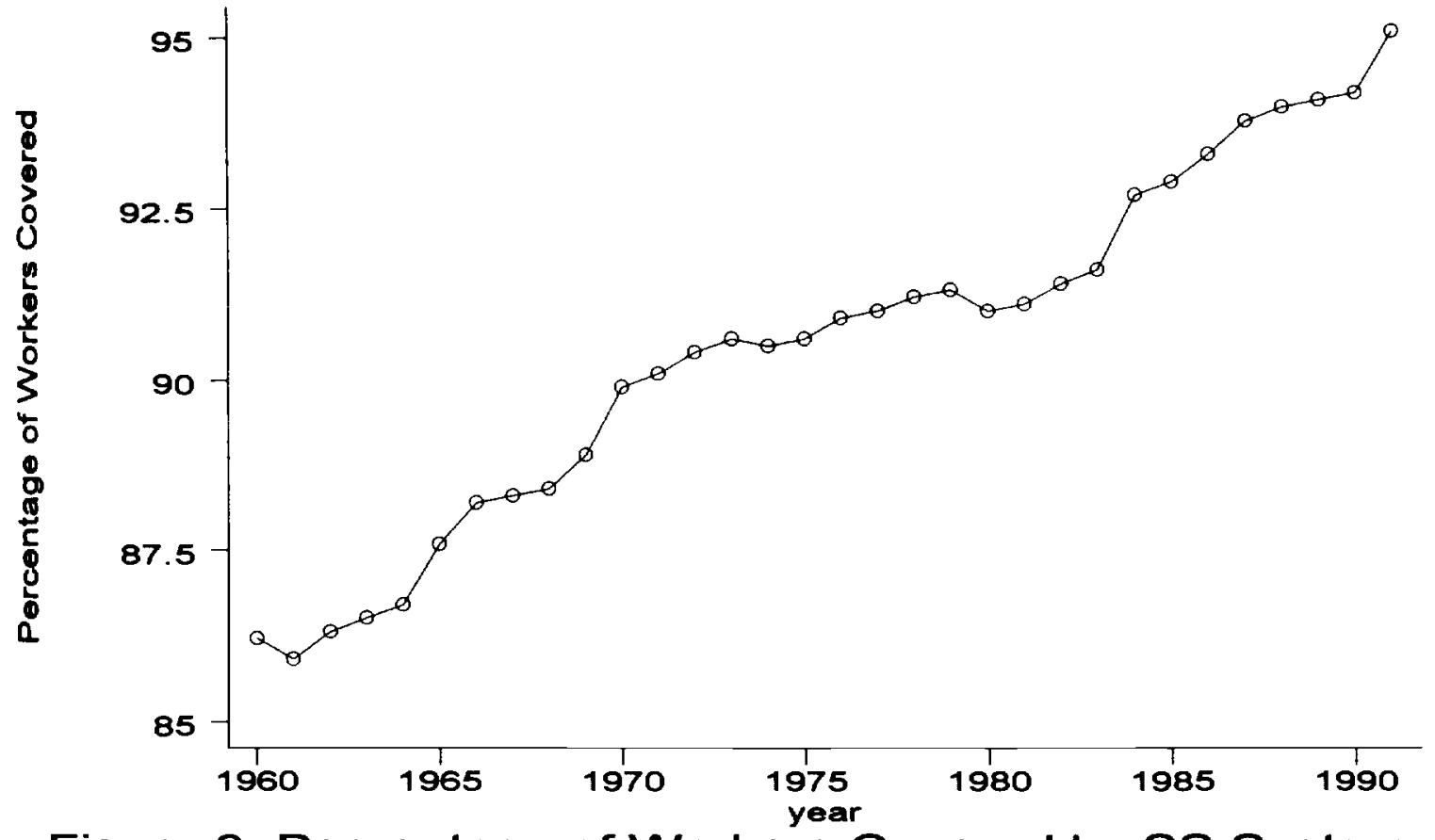

Figure 3: Percentage of Workers Covered by SS System 


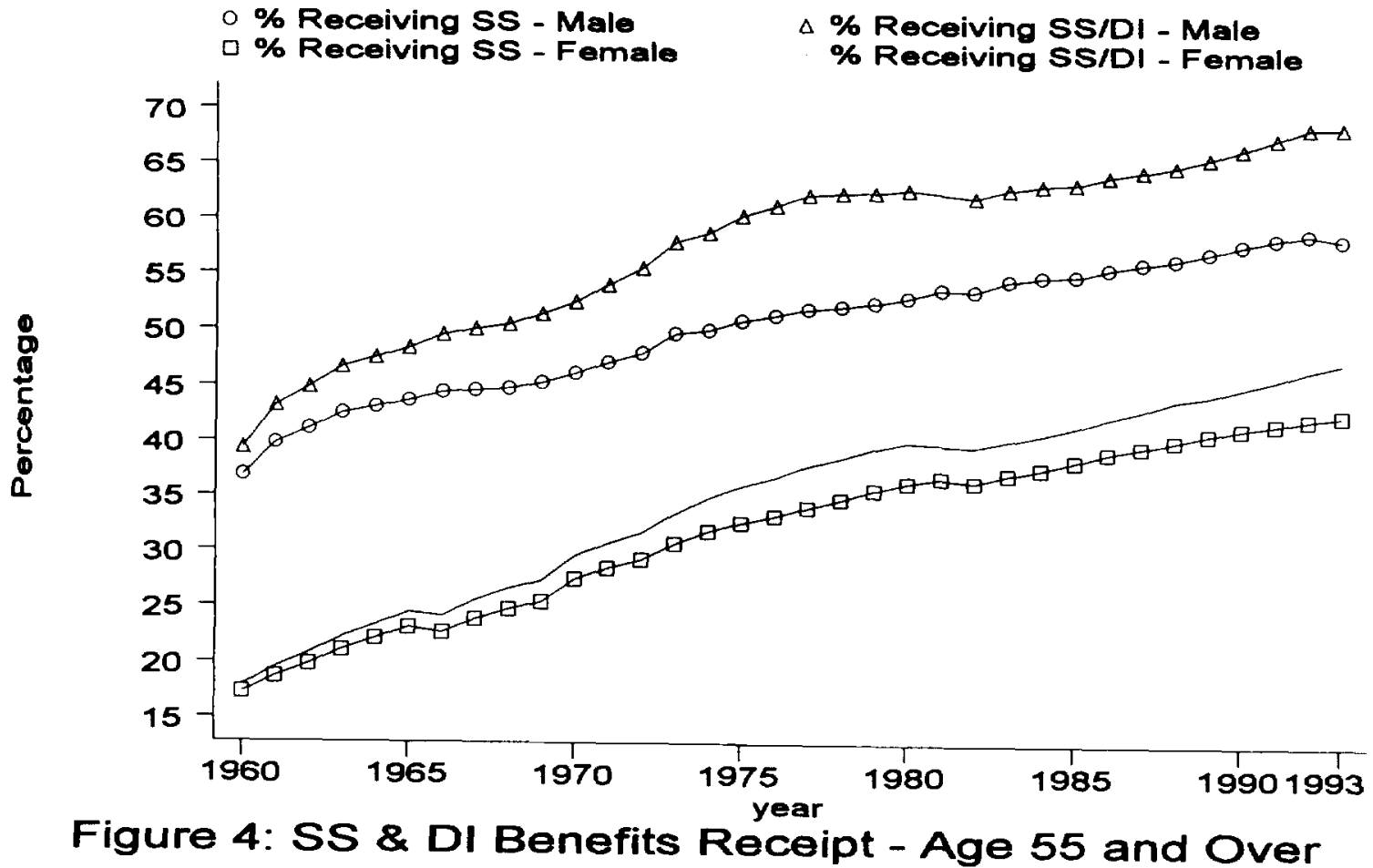




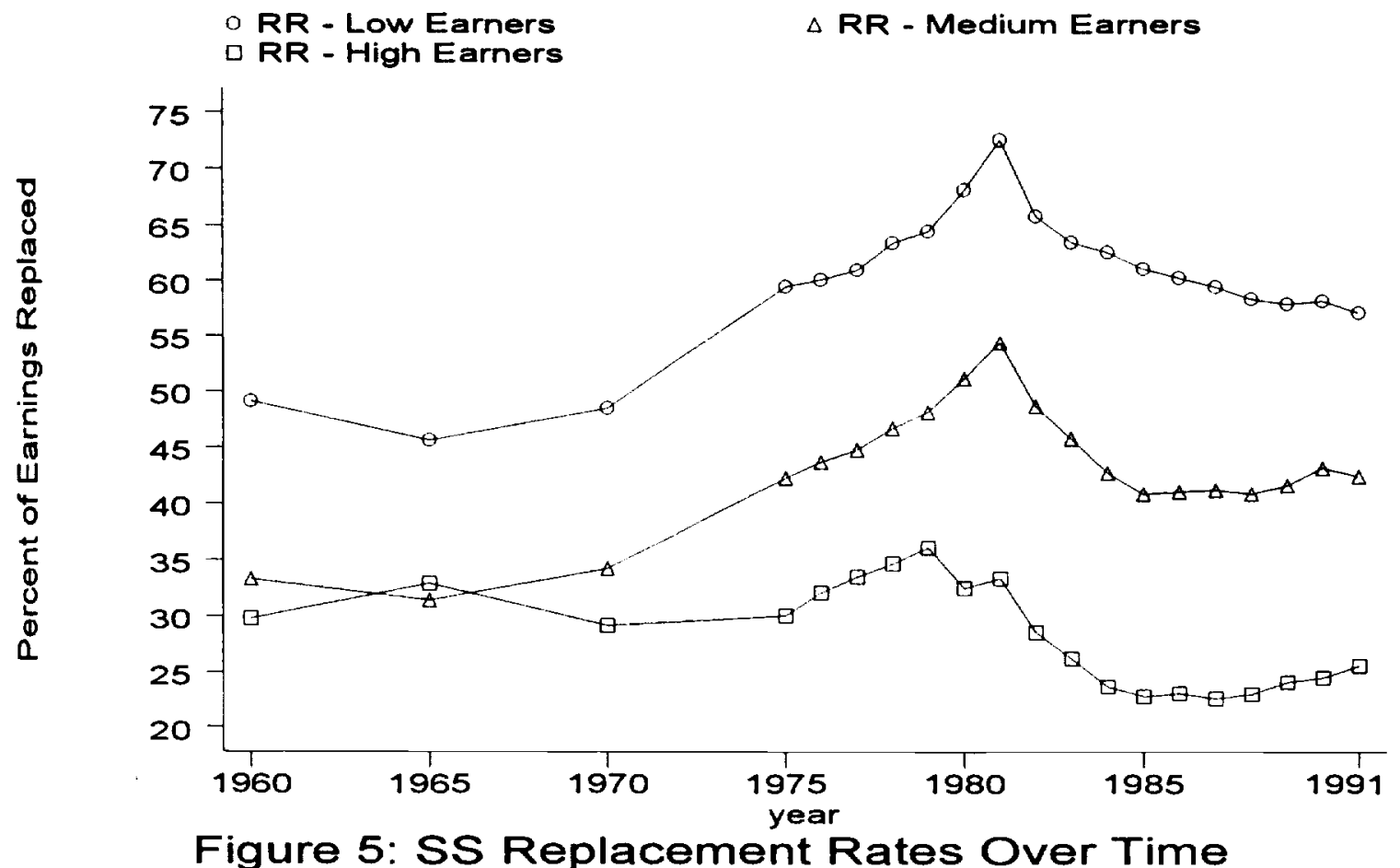

Figure 5: SS Replacement Rates Over Time 


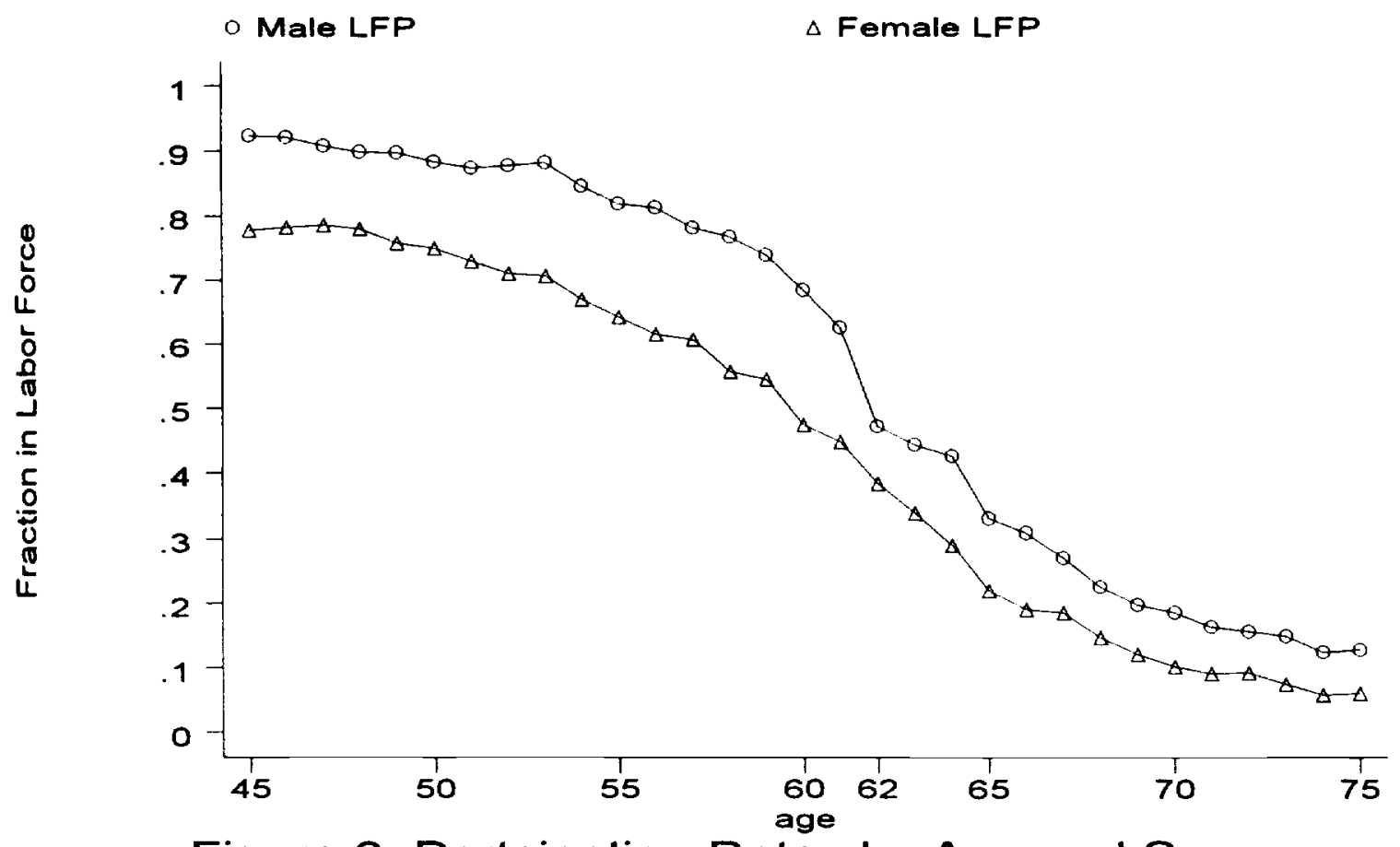

Figure 6: Partcipation Rates by Age and Sex 


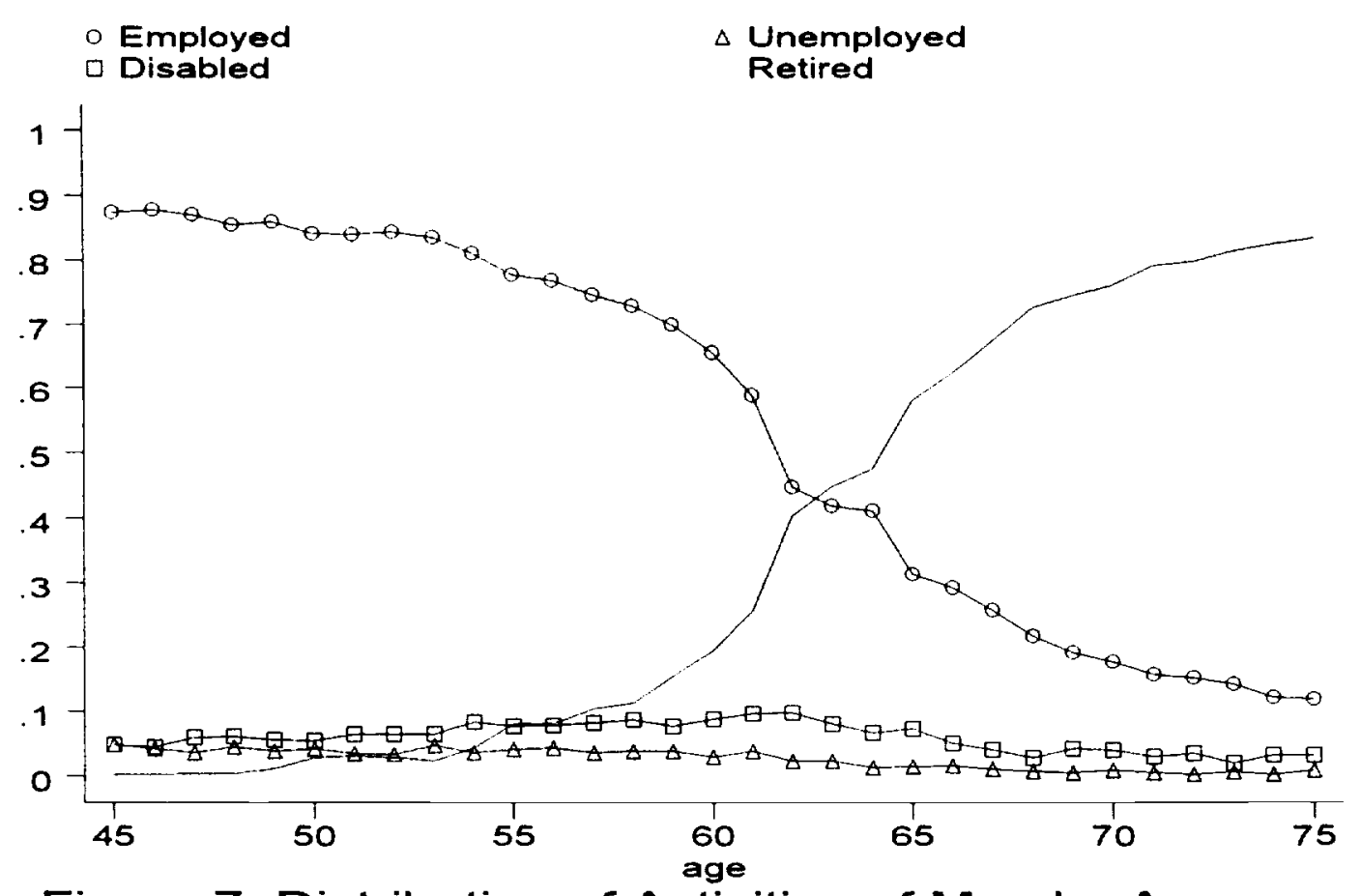

Figure 7: Distribution of Activities of Men by Age 
- Employed

$\square$ Disabled

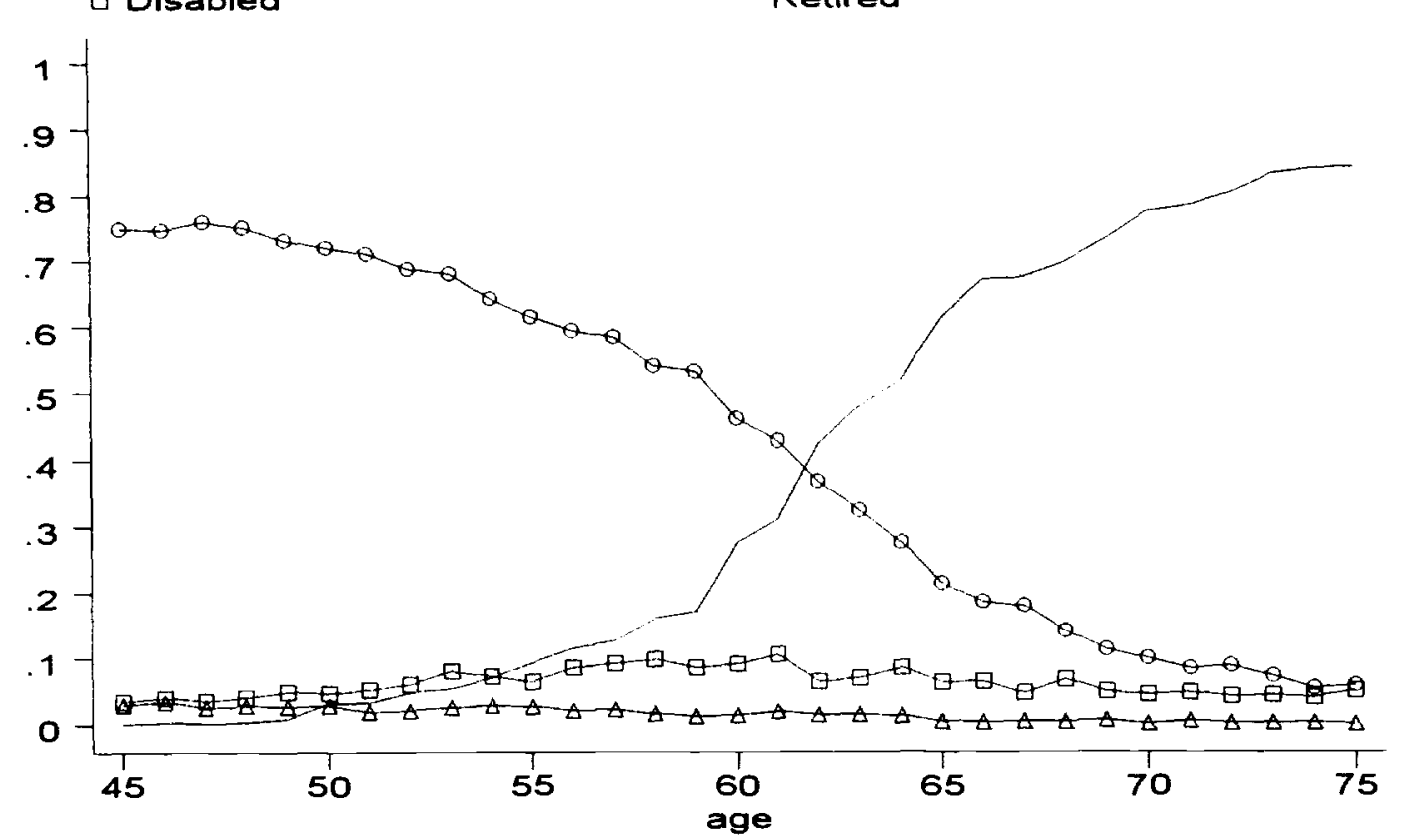

Figure 8: Distribution of Activities of Women by Age
$\Delta$ Unemployed

Retired 


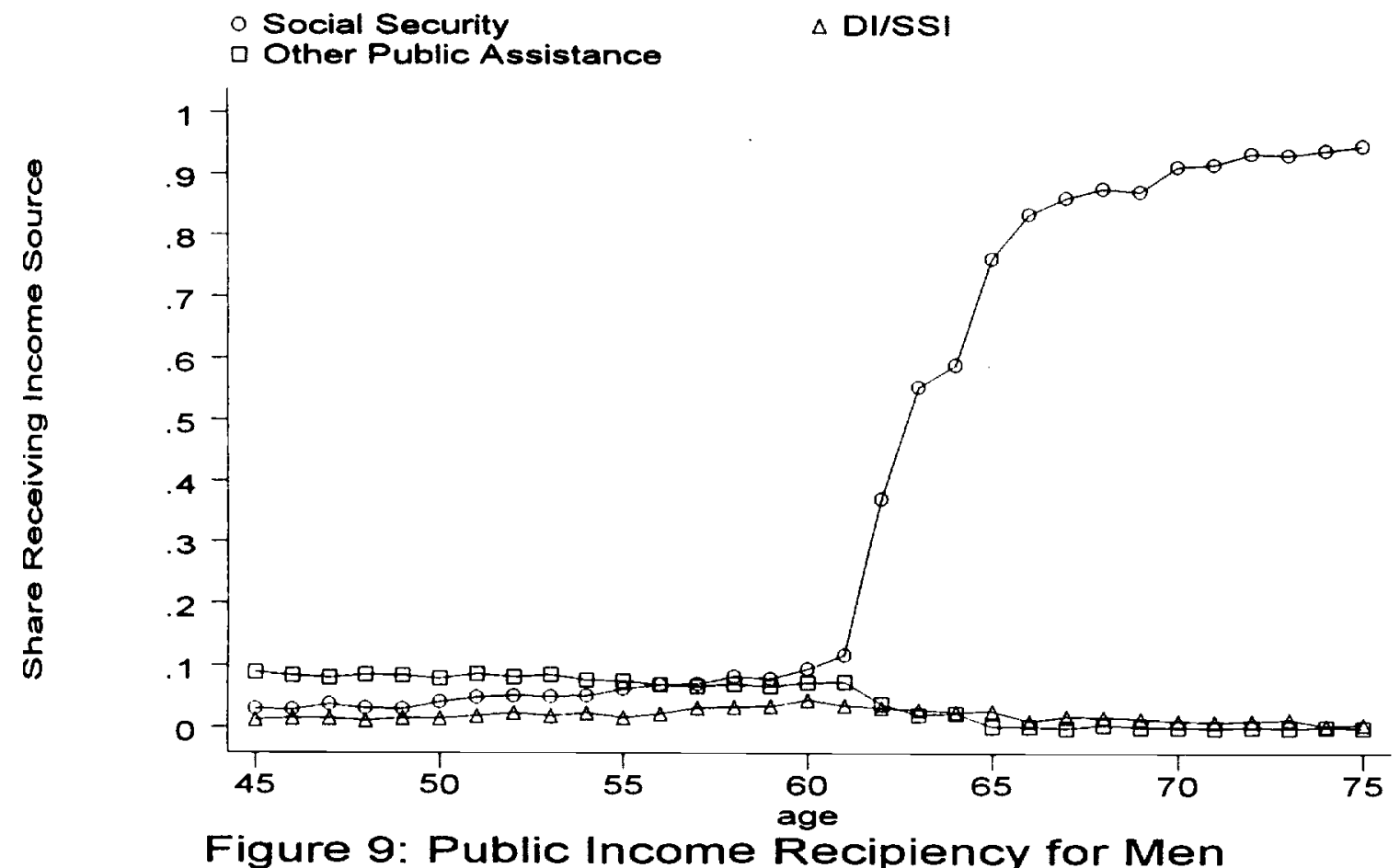

Figure 9: Public Income Recipiency for Men 
- Males

$\triangle$ Females

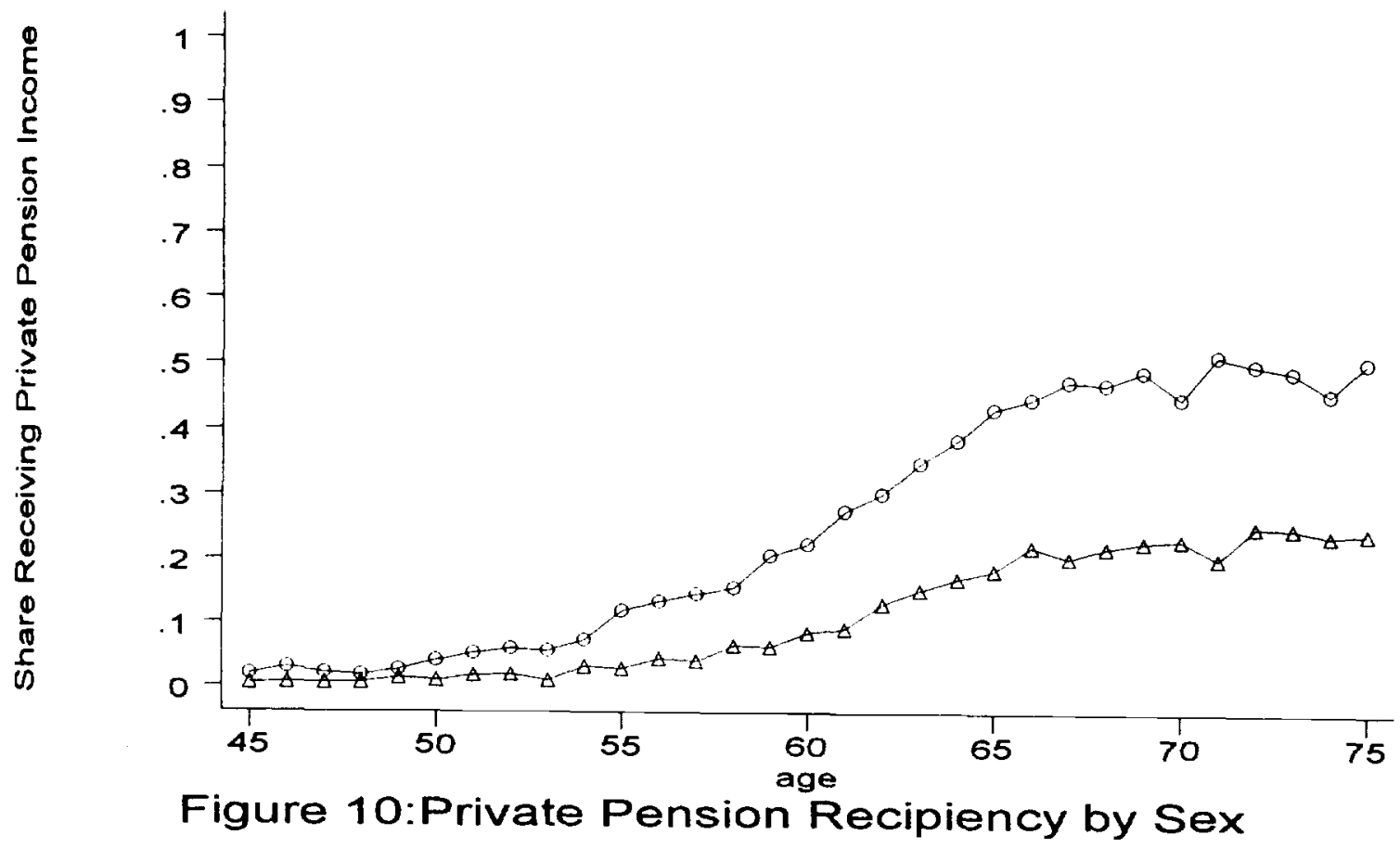




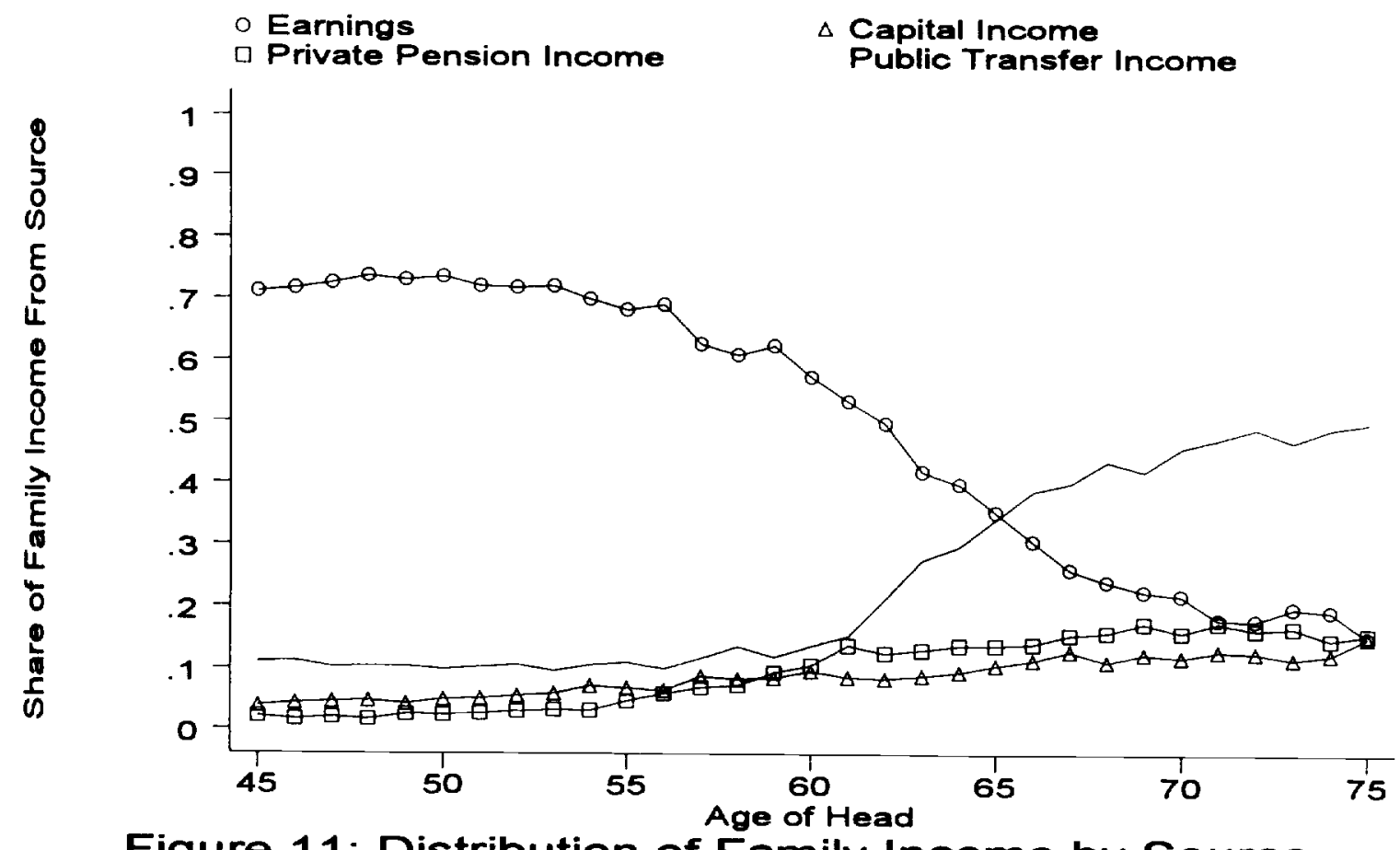

Figure 11: Distribution of Family Income by Source 


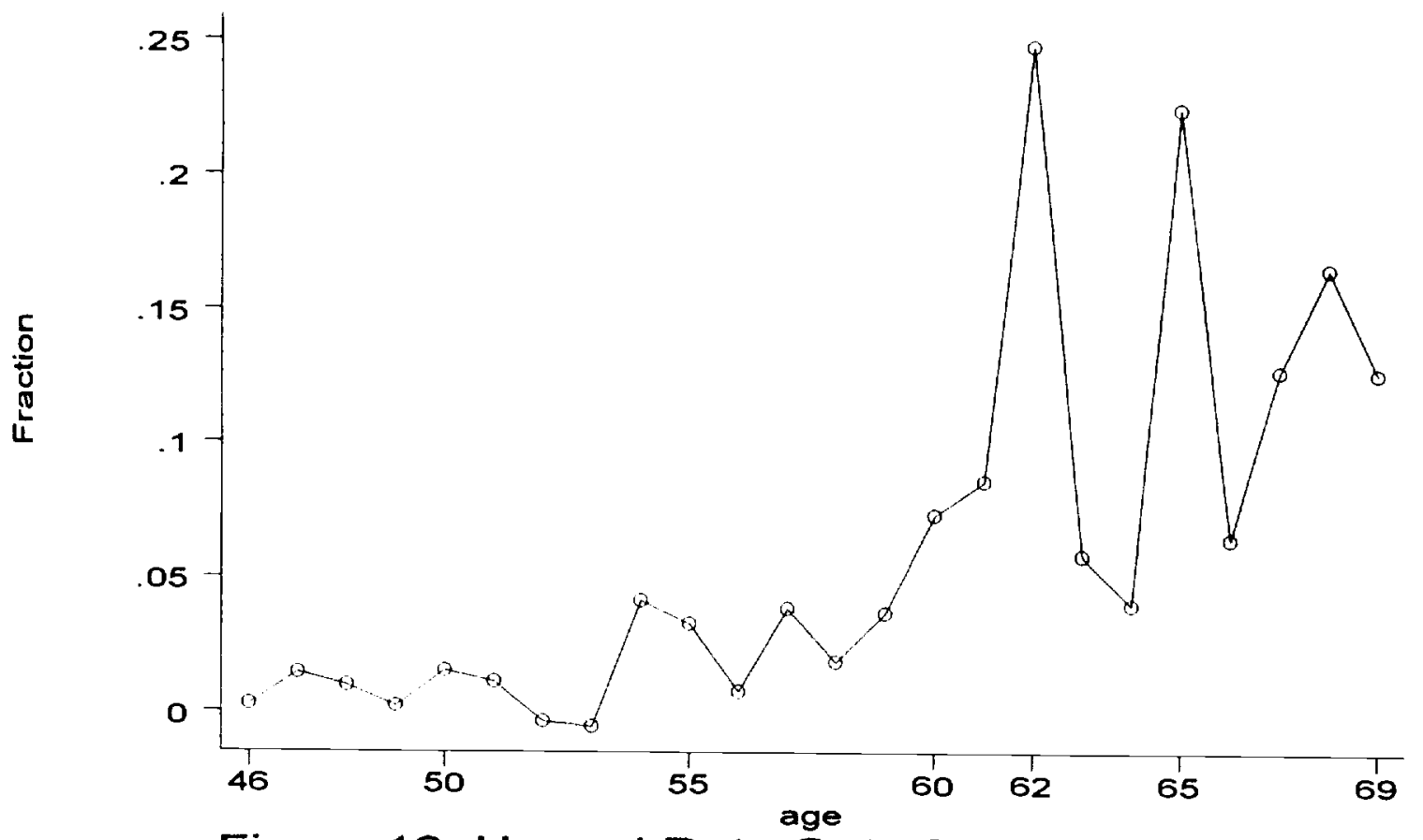

Figure 12: Hazard Rate Out of LF for Men 


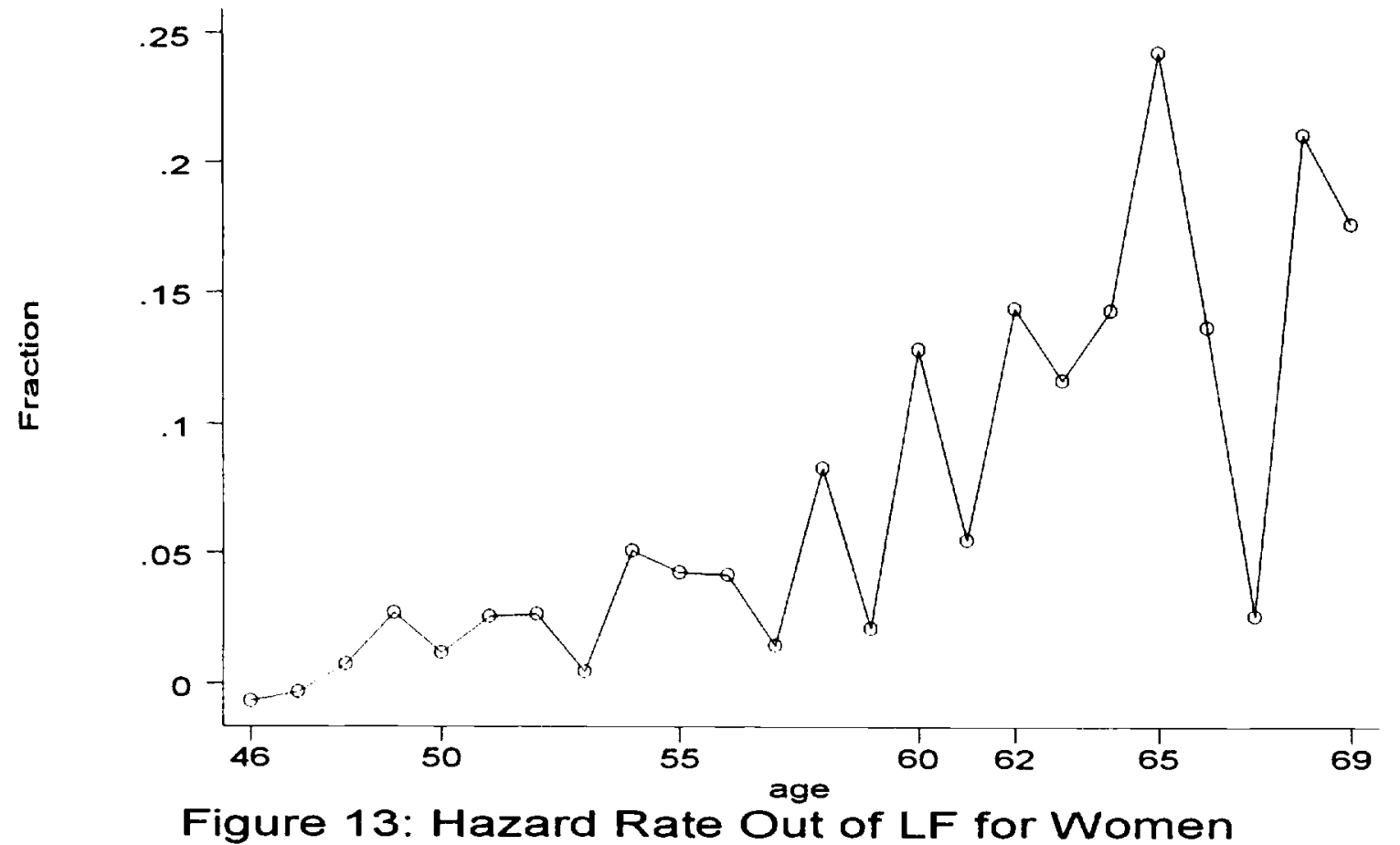

Figure 13: Hazard Rate Out of LF for Women 
Figure 14: Tax/Subsidy Rates Across Earnings Profiles

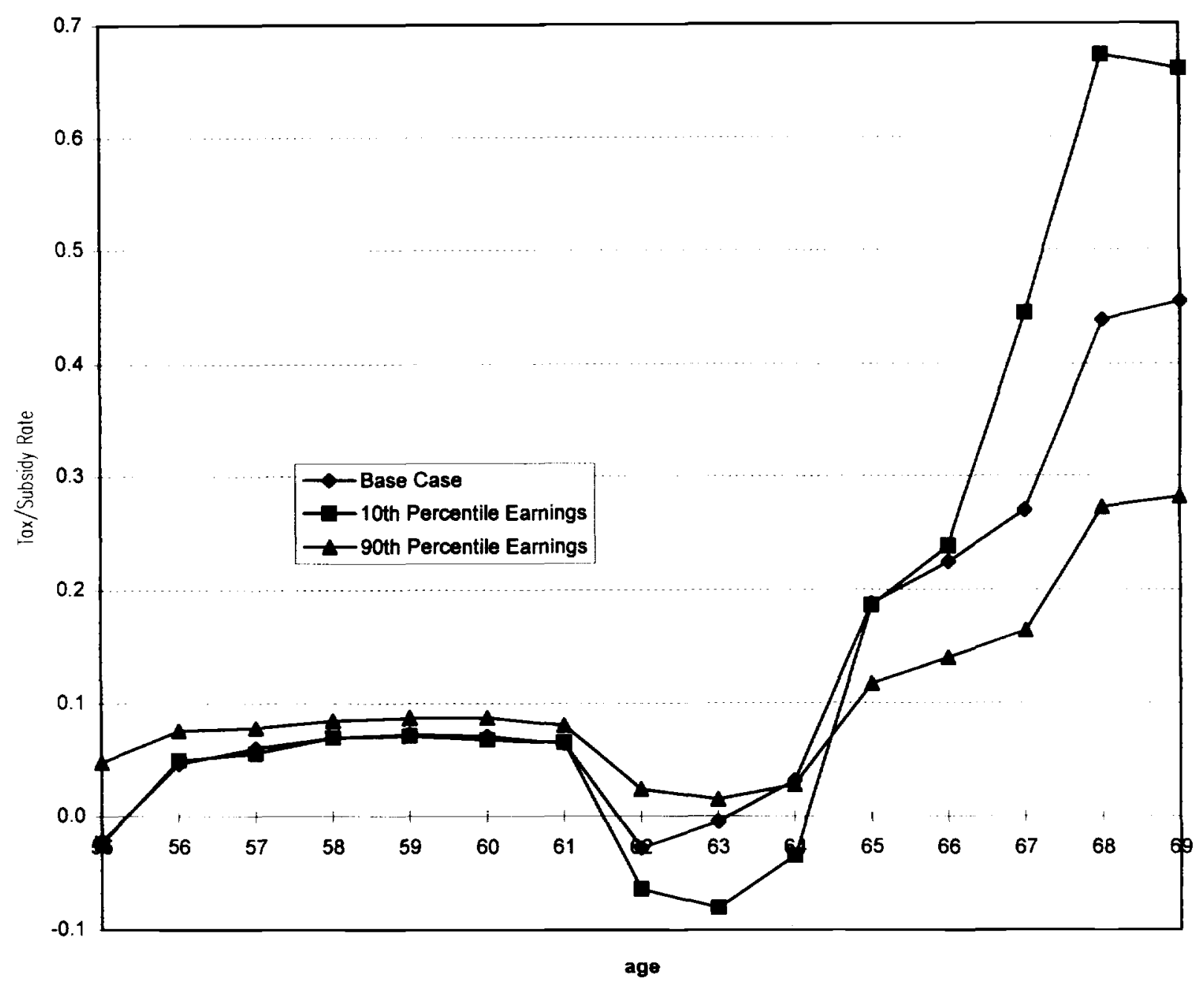

